DANMARKS GEOLOGISKE UNDERSOGELSE

II. Række. Nr. 100

Geological Survey of Denmark, II. Series, No. 100

\title{
Geochemical and sedimentological investigations of the Rosenholm Depression
}

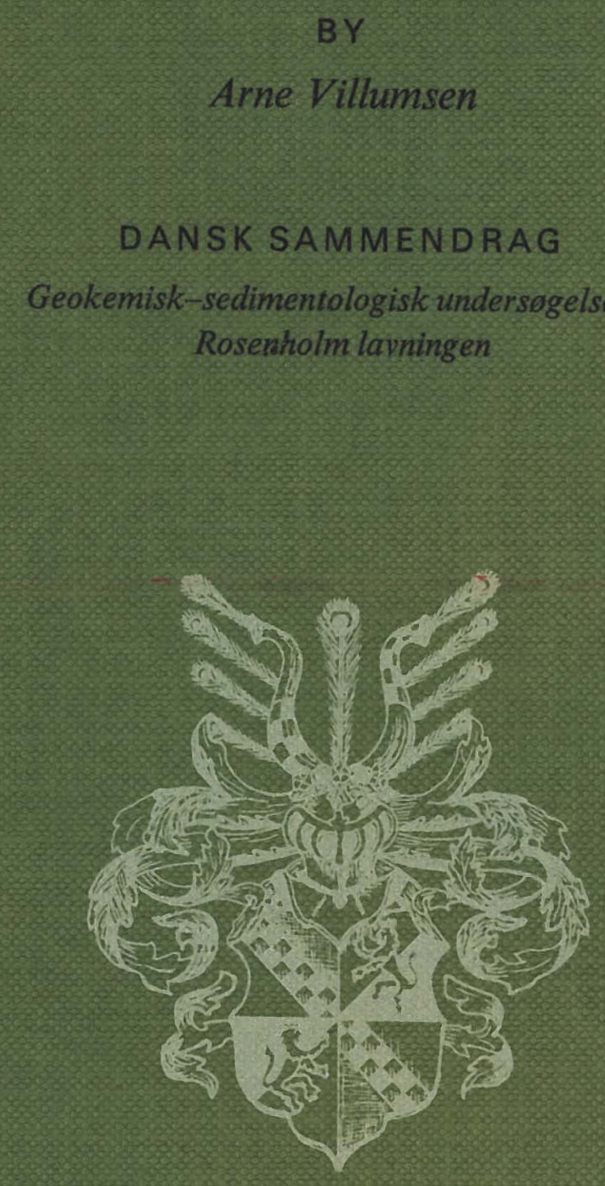


DANMARKS GEOLOGISKE UNDERSØGELSE

II. RÆKKE . NR. 100

Geological Survey of Denmark. II. Series. No. 100

\title{
Geochemical and sedimentological investigations
}

\author{
of \\ the Rosenholm Depression
}

\author{
By \\ Arne Villumsen
}

Dansk sammendrag:

Geokemisk-sedimentologisk undersøgelse af

Rosenholm lavningen

I kommission hos

C. A. REITZELS FORLAG

KøBENHAVN 1973 
D.G.U. II rk. nr. 100

er sat med Linotype Times

og trykt i 1500 eksemplarer

hos Andelsbogtrykkeriet i Odense.

Bogen er trykt på ekstraglittet 605, $125 \mathrm{~g}$

og plancherne på Top-Cote 101, $120 \mathrm{~g}$

fra a/s De forenede Papirfabrikker

ISBN 8742106249

With 2 plates

Date of publication: 1973-02-15 


\section{CONTENTS}

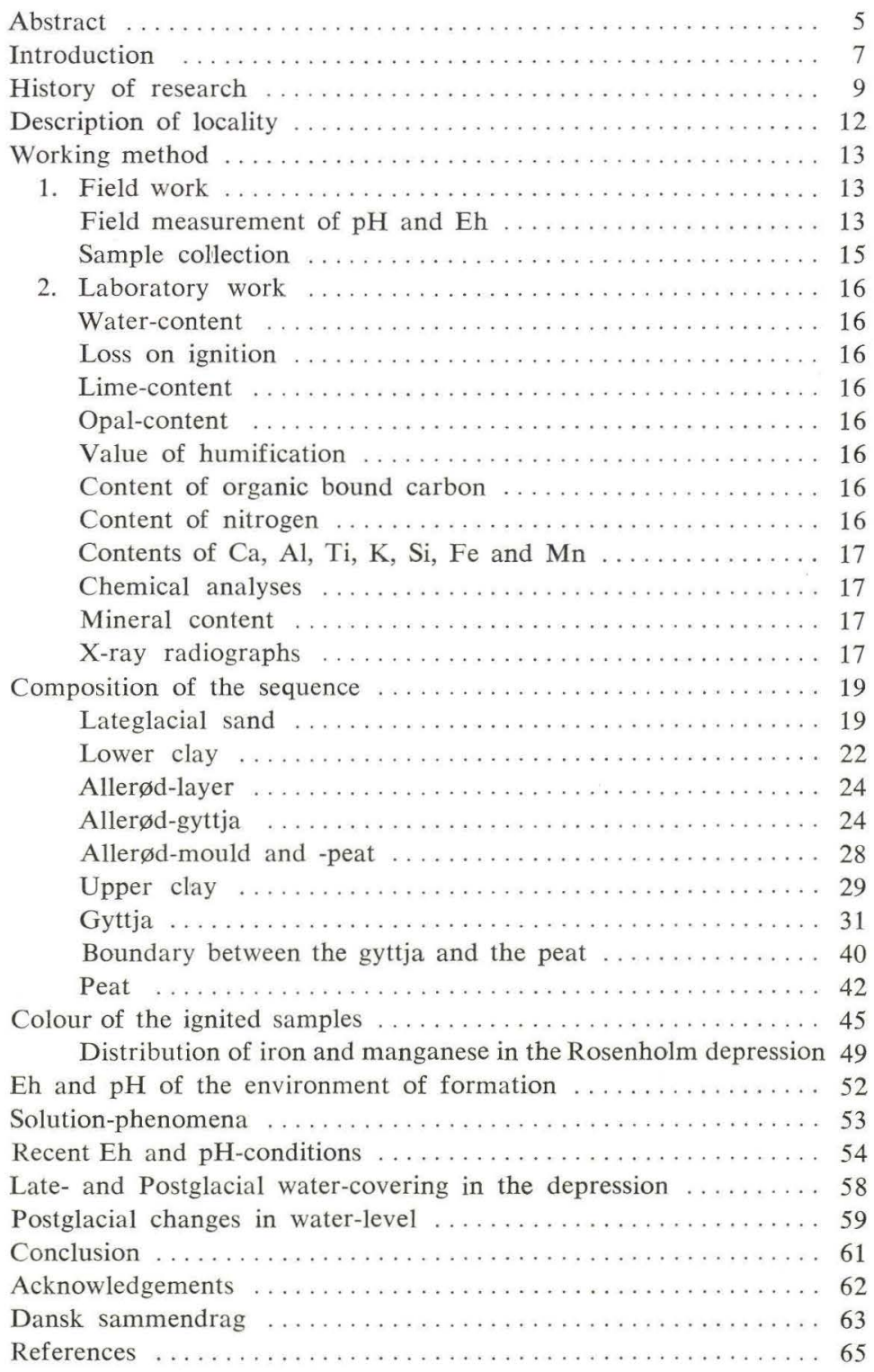




\begin{abstract}
The Rosenholm depression is investigated as an example of the development of the conditions of sedimentation for the Late- and Postglacial freshwaterdeposits in the area between Aarhus and Randers. The sequence, which in places is 12 metres thick, includes creeping soil, meltwatersand, outwash clay, Allerød-gyttja, -mould, and -peat, outwash clay and Postglacial gyttja and peat.

The surface of the meltwatersand was mapped by borings; the bottom topography seems to support the assumption that the depression has had a subglacial past (tunnelvalley).

The Allerød-oscillation can be separated into three different facies: The NW-part has euxinic gyttja, and the SE-end has Allerød-mould and -peat.

In the succeeding Postglacial lake-phase gyttja was deposited in the NW-part, while the bottom sediment in the SE-stern end (separated from the rest of the depression by a sand barrier) was composed of dy and tyrfopel. After this the basin continued to be divided into two parts until peat covered the whole area.

Measurements of acidity $(\mathrm{pH})$ and redoxpotential $(\mathrm{Eh})$ indicate that the whole series of layers are undergoing decomposition at the present time.
\end{abstract}




\section{INTRODUCTION}

An important part of the Quaternary landscape on the RANDERS MAP SHEET is formed of valley systems which are believed to have a genetically complex past (LARSEN 1972).

This paper illustrates the Late- and Postglacial development of the valleys as shown by investigations carried out in the Rosenholm depression.

This depression is an elongated peat-filled hollow in the young-glacial landscape in front of the Harder border moraine. It takes its name from Rosenholm castle, which is situated between the villages of Hornslet and Mørke in the eastern part of the Randers map (fig. 1).

The aims of the investigations were to find the limits of the Rosenholm depression in the terrain, to characterize the sediments and to give an account of the condition of sedimentation in the basin during Late- and Postglacial time. 


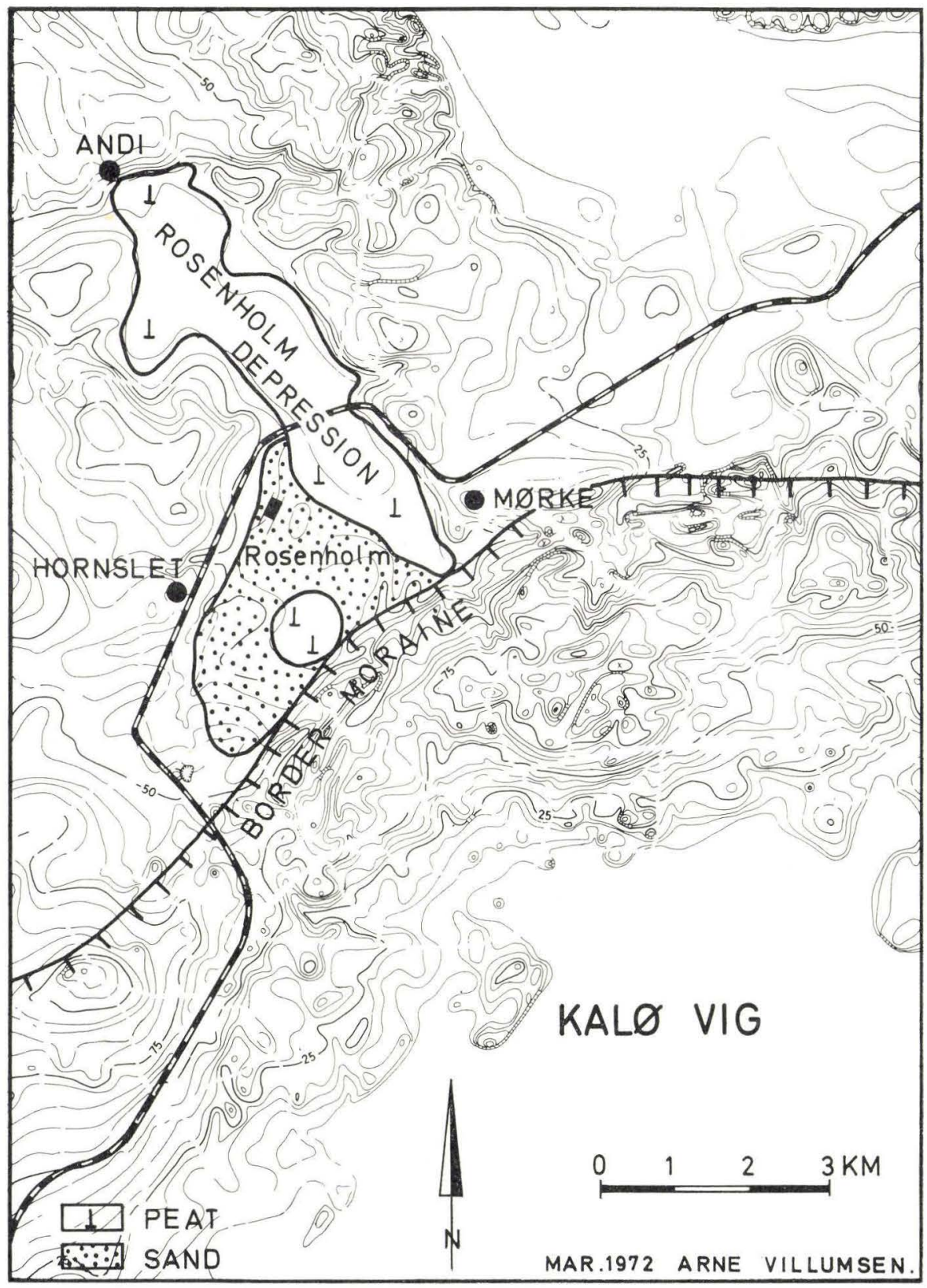

Fig. 1. Printed with permission (A.225/72) from Geodætisk Institut. 


\section{HISTORY OF RESEARCH}

The depression is the youngest part of a landscape complex which includes the Kalø Vig (Kalø Creek) central depression, part of the Harder border moraine, and Hornslet outwash plain (fig. 1).

HARDER (1908) explained the course of the iceborder line in this area and pointed out the genetic relationships which exist between the landscape elements: The ice-offensive through Kalø Vig gave rise to a border moraine, which in the area between Hornslet and Mørke obstructed the drainage towards the S and SE, forcing the meltwater to flow to the NW. The Hornslet outwash plain is partly formed by this stream of meltwater and partly by water from melting ice in the area farther to the SW. The Rosenholm depression was at this time a meltwater lake from which the water drained through an outlet in the NW and reached the great valley-systems. Harder (1908, p. 219) quotes: "It is a not unimportant lake which first arose at this (Lateglacial) time in the low lying terrain near Rosenholm and which remained in existence until Postglacial time". Milthers (1931) showed by counting indicator-boulders, that the ice during the Kalø Vig-offensive moved from south to north. GRY (1935) found the same ice-direction from investigations of the Paleocene marl at Ommestrup Brickworks SE of Mørke.

Geological investigations of the Rosenholm depression itself have not been carried out before the present work. However, the peatcover of the depression has been mapped by Hedeselskabet (1927-1928) as part of a major project, the aim of which was to register the fuel-reserves in the more extensive bogs of Denmark (THøGERSEN 1942).

The sediments in the Rosenholm depression consist of a series of Postand Lateglacial freshwater formations including:

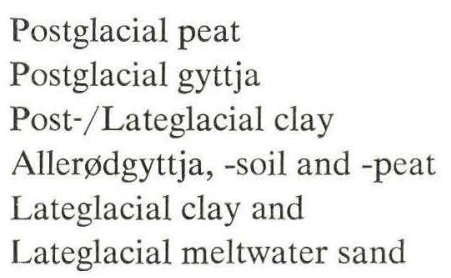

This stratification, which is often found in the bogs of Denmark, has been the subject of much research and some of the Danish contributions to boginvestigations are mentioned below.

The study of bog-geology in Denmark was started by DaU $(1823,1829)$ who put forward the theory of a forestdevelopment which STEENSTRup 
(1842) related to a general warming up of climate conditions. Investigations at Allerød Brickworks pit (HARTZ and Milthers 1901) showed that the rise of temperature was not uniform after the ice had disappeared (the Allerød-oscillation). The influence of man on the forest composition was demonstrated by IVErSen (1941). IVERSEN (1954) and ANDERSEN (1969) showed the importance of soil development. The great number of pollendiagrams gave a detailed insight into the Late- and Postglacial pattern of development, and at the same time gave the possibility of biostratigraphically relative dating before $\mathrm{C}^{14}$-datings were available. From the early fifties $\mathrm{C}^{14}$-datings were used in Denmark (HANSEN 1965), and the relative ages determined by pollenanalysis could be converted to an absolute scale.

The Gyttja: The first bog-investigators worked on the peat only, but it soon became clear that the deeper parts of the bogs with layers of gyttja and clays should also be studied. The gyttja-layer was mentioned for example by Steenstrup (1842, p. 28), but the prominent work of H. von Post (1862) gave a deeper understanding of gyttja formation. The explanation of von POST of the gyttja- and dy relations is of particular importance. He attached significance to the coprogenic processes which transform the mixture of organic and inorganic substance of the lake bottom. In 1901 WESENBERG-LUND's treatise appeared, which is one of the best Danish papers on lake sedimentation. He draws attention to the fact that the chemistry of the surrounding area governs the lake development and explains why the majority of the Danish lakes are calcareous. The lime, which is carried to the lake in solution, can be deposited on plant leaves, in stems etc. in the environment close to the plant, as a result of the $\mathrm{CO}_{2}$-assimilation during photosynthesis. Either by the death of the plant or by falling from the living plant the lime is accumulated as a sediment. The lime-producing organisms seems-according to WeSENBERG-LUND - to distribute themselves in different belts depending on depth. The gyttja is formed, as von PosT believed, by a mixture of organic and inorganic material by a coprogenic transformation. WeSEnBERG-Lund adds that the gyttja, after passage through the intestinal canal of the bottom fauna, becomes lighter in colour i.e. the content of organic material is reduced.

The requirement for a continous formation of gyttja is that a state of balance is established on the lake bottom between supply of organic matter and the transformation-capacity of the bottom fauna. If the supply of plantmaterial is too great, the humic acids will inhibit the activity of the bottom animals, and dy or peat will be formed instead of gyttja (WESENBERG-LuND 1901, p. 97).

WeSENBERG-Lund continued his studies in Lake Fures $\varnothing$ (1917), where he directed a team of research-workers carrying out a large-scale investigation of the lakes of the Møllea river. The chief aim of the investigation was mapping (depth contouring, fauna and flora mapping). The distribution of 
iron ore which WESENBERG-LUND found in 1901 was also mapped and its formation related to a special state of oxidation on the lake bottom.

Classification of the lakes: In about 1920 the lakes were classified (e. g. by NaUmanN 1917, 1919) according to their biological, or their potential, biological production. NAUMANN drew attention to the content of $\mathrm{N}$ and $\mathrm{P}$, which are still considered to be important nutrients. Lakes with a high content of $\mathrm{N}$ and $\mathrm{P}$ are called eutrophic, while lakes with a poor content of nutrients are termed oligotrophic. THIENEMANN (1921 and 1925) added a third type, the dystrophic, which are characterised by their content of colloidal humic matter, giving a brownish colur to the water.

The attemps of classification centred around NAUMANN's and THIENEMANN's tripartite division (eu-, oligo- or dystrophic). There was widespread agreement that the water of the dystrophic lake is brown-coloured as a result of the presence of humic matter. On the other hand the genetic position of the brown-coloured water was not clear. In 1862 vON PosT stated that the dy is a gyttja which has received a supply of humic matter from outside the lake basin. JÄRNEFELT (1952, p. 205) asserted, as did VON POST, that the brown coloured water is a result of humus which is supplied from areas outside the real lake-domain, and therefore a genetically special lake type should not be set up to account for the dystrophy. Both eutrophic and oligotrophic lakes can periodically be brown-coloured. The bipartite lake-classification of JäRNEFELT (eu- and oligotrophic) is based on the biological production.

Hansen (1961, 1962, 1964, and 1966) classifies the lakes according to their bottom-sediments. He proposed a classification according to the trophyand humusstate of the lakes. The trophy is measured in the lake sediment by its content of biogenic lime and silica (opal) and the humus-state by the $\mathrm{C} / \mathrm{N}$-ratio:
A. Oligohumous lakes with gyttja
a. Oligotrophic
b. Eutrophic
B. Polyhumous lakes with dy or tyrfopel
a. Oligotrophic
b. Eutrophic

The oligohumous lakes pass via the polyhumous to peatbogs by overgrowing.

Researches in Danish lakes have since the turn of the century, with a few exceptions, been carried cut by biologists who have divided the lakes into two chief types, the oligotrophic and the eutrophic, and into a series of subtypes based on fauna and flora.

The sediments under recent lake bottoms have only been investigated in a few cases: in Lake Gribs $\varnothing$ (Hansen 1956), Lake Grane Langs $\emptyset$ (Hansen 1964) and Lake Esrom Sø (Hansen 1968). 


\section{DESCRIPTION OF LOCALITY}

The investigations included two separate, peatcovered basins: The Rosenholm depression and the bog of Hornslet.

The bog of Hornslet is situated approximately $1 \mathrm{~km}$ south of Rosenholm castle and is surrounded on all sides by the Lateglacial meltwatersand, which constitutes the Hornslet outwash-plain (fig. 1). About $1 \mathrm{~km}$ north of the bog of Hornslet lies the Rosenholm depression which extends about $6 \mathrm{~km}$ in a NW-direction. The basin is on average about $1 \mathrm{~km}$ wide. The Rosenholm depression is enclosed on three sides by hills of moraine clay and diluvial sand. From the village of Hornslet the terrain slopes gently towards the SEpart of the depression. The peatcover is almost horizontal with a slight downwards incline to the NW. The Rosenholm depression is situated at about $13 \mathrm{~m}$ and the bog of Hornslet at about $15 \mathrm{~m}$ above sea level. Peat is no longer removed from the Rosenholm depression. After several attemps at drainage, agriculture has been made possible in most places. An exception to this is Mørke Kær, where a large area is watercovered. The depression is drained by the Rosenholm river which has its outlet near Andi in the NW part. 


\section{WORKING METHOD}

\section{Field work:}

The investigations were started by surface mapping a suitable area surrounding the depression. After this a systematic depth-mapping of the demarcated basin was carried out using a Hiller-type corer. The core samples were described; $\mathrm{pH}$ - and Eh-determinations were made in the field, and samples were collected for laboratory investigations.

\section{Field measurement of $\mathrm{pH}$ and Eh:}

These were carried out by a transportable $\mathrm{pH}$-meter of type PHM 29 (Radiometer). For the $\mathrm{pH}$ measurings a combined glass- and referenceelectrode (type G. K. 2311 C) was used. The calibration of the apparatus was controlled at frequent intervals, and at least once a day by means of a standard buffer-solution with $\mathrm{pH}=6.5$. The $\mathrm{pH}$-measurements could be reproduced with an accuracy of \pm 0.1 .

The Eh-values were determined as the potentialdifference between a platinum electrode (type P 101) and a calomelelectrode (type K 401). The selfpotential of this calomelelectrode is $+244.4 \mathrm{mV}$ at $25^{\circ} \mathrm{C}$. The correction for the eletrode-configuration chosen was practically fixed to $+250 \mathrm{mV}$, as the temperature of the pore-fluid was fairly constant at about $18^{\circ} \mathrm{C}$. The apparatus was calibrated at least once a day in a saturated solution of quinhydrone. The Eh-measurements could be reproduced with an accuracy of \pm $10 \mathrm{mV}$. The theoretical background for the method of Eh-measurement has been discussed by Petersen (1966).

Both pH- and Eh-measurements were carried out in the field on the fresh core sample immediately after the corer had been opened. Measurements were systematically taken at $20 \mathrm{~cm}$ intervals. The importance of measuring $\mathrm{pH}$ and $\mathrm{Eh}$ in the field on the fresh sample is illustrated by figure 2, from the boring Smedegrave 40. The Eh-values taken after 6 hours are about $100 \mathrm{mV}$ higher than the fieldvalues. The samples above the groundwater-table show no changes in Eh. The $\mathrm{pH}$-values in the peat and in the sand are about the same by field and laboratory measurements. In the calcareous gyttja a $\mathrm{pH}$-increase from about 6.4 to 7 occurs during the 6 hours. The acid pore-fluid has consequently been partly neutralized by the lime. It is to be expected that the $\mathrm{pH}$-values in this material will rise further until the theoretical value of equilibrium (ca. 7.8) has been reached 


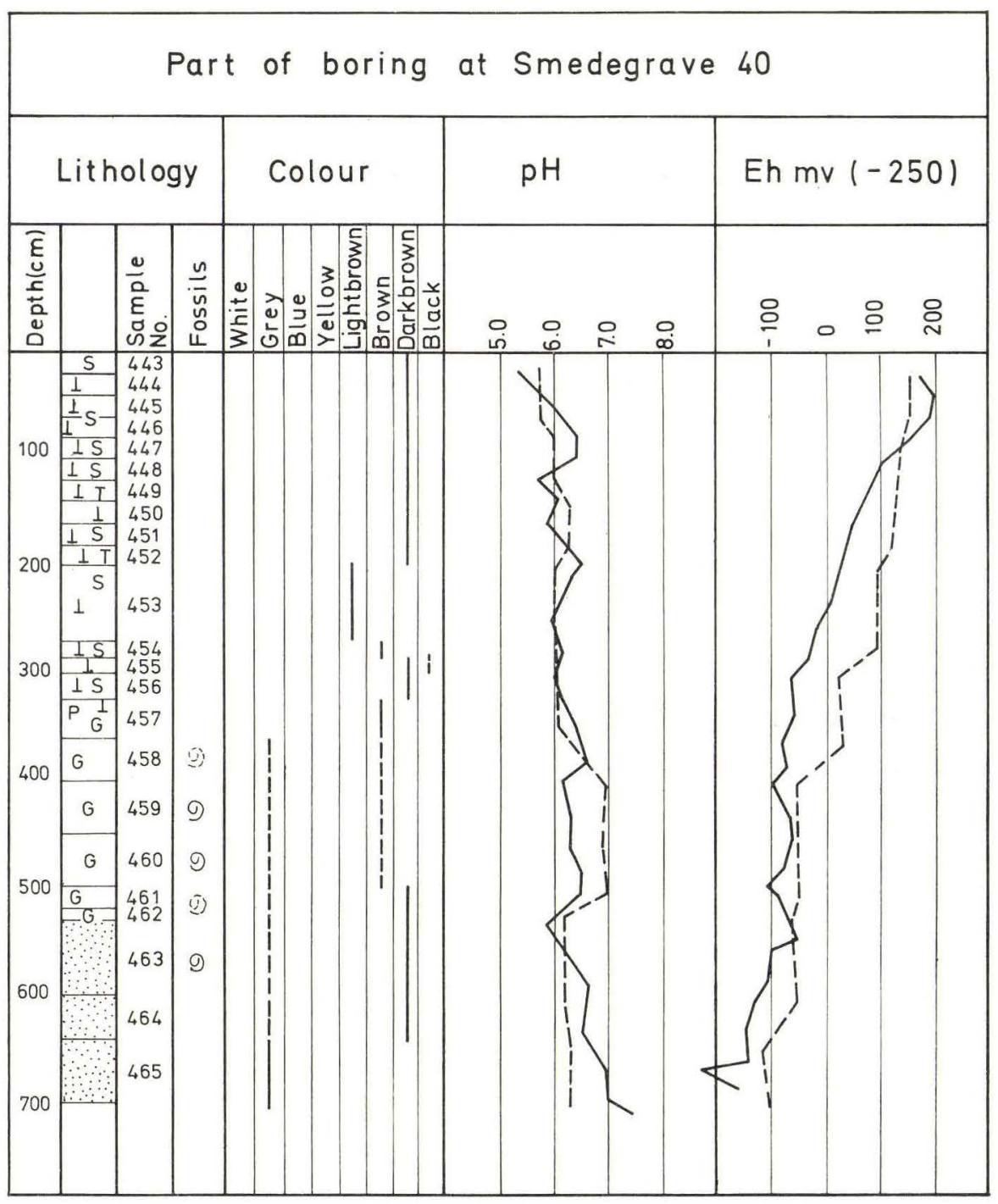

Fig. 2. Full line indicates values determined in the field. Dashed lines are the laboratory measurements carried out ca. 6 hours later on the same material. ( $\mathrm{S}=$ sphagnum peat; $\perp=$ peat; $\mathrm{P}=$ plant remains; $\mathrm{G}=$ gyttja; corroded fossils are shown by dashed signature).

(KRUMBEIN and GARRELS 1952). Laboratory-measurement of $\mathrm{pH}$ and $\mathrm{Eh}$ are therefore not reliable for this type of investigation. All determinations of $\mathrm{pH}$ and Eh in the Rosenholm depression were carried out as field measurements. 


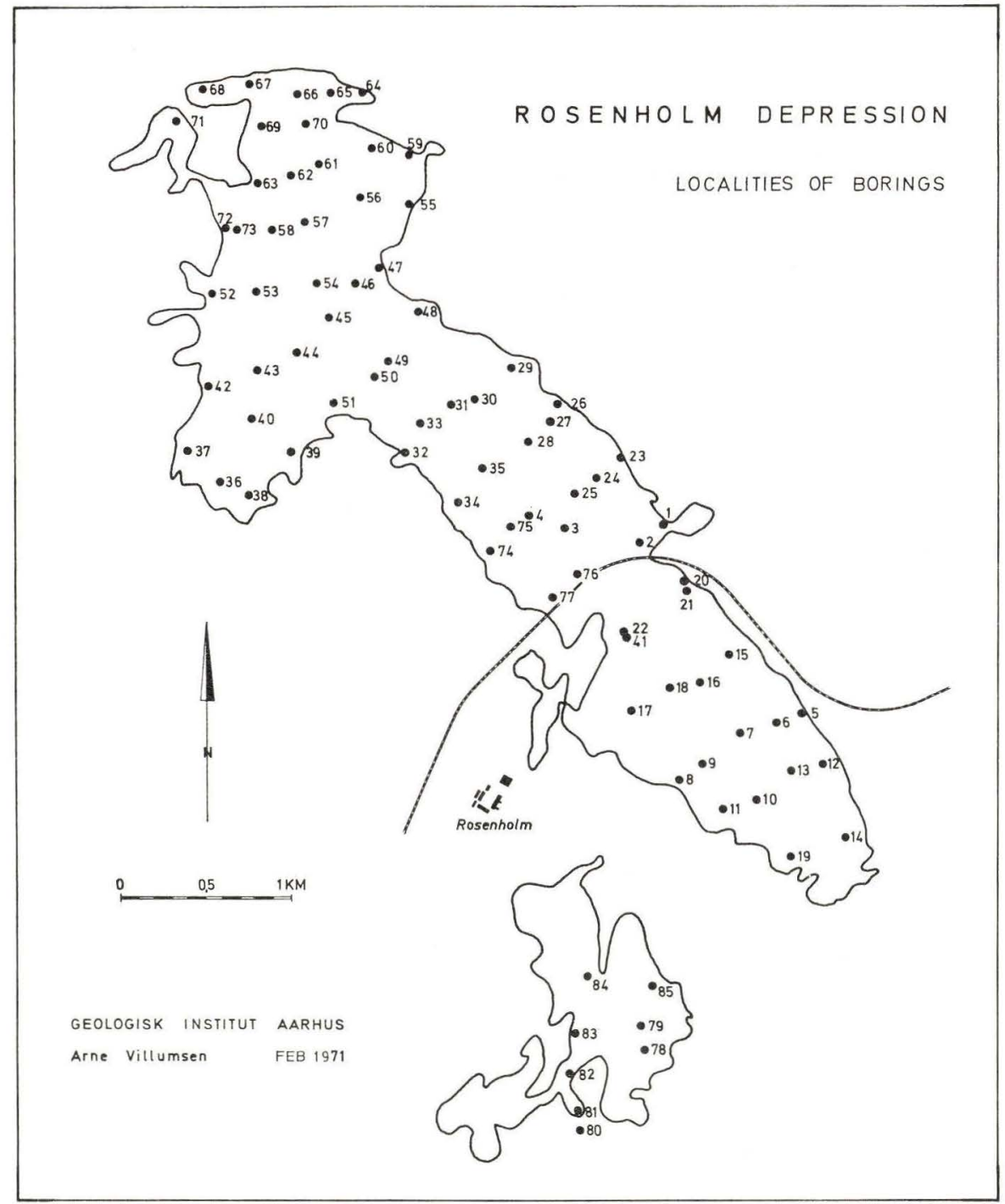

Fig. 3.

\section{Sample collection:}

It appeared that the sediments varied widely in colour and lithology. Samples were taken to represent all variations. One single boring was carried out with boring-equipment type Geonor A/S, $54 \mathrm{~mm}$ sampler. The cores from this boring were brought intact to the laboratory for photographing and for taking X-ray radiographs. A total of 85 borings were made on profiles across the depression with $400-500 \mathrm{~m}$ between each profile. The locations of the borings are shown in fig. 3 . 


\section{Laboratory work:}

The following determinations were made on the samples studied in the laboratory; Water-content; Loss on ignition; Lime-content; Opal-content; Value of humification; Content of organic bound carbon; Contents of $\mathrm{Ca}, \mathrm{Al}, \mathrm{Ti}, \mathrm{K}, \mathrm{Si}, \mathrm{Fe}$ and $\mathrm{Mn}$ in the ignited samples. Chemical analyses of 4 samples were carried out before and after the ignition. In addition the mineral content of some selected unignited samples and a few ignited ones were determined. X-ray radiographs from parts of the profile were taken.

Water-content is indicated as weight $\%$ of dry matter and was determined by drying at $100^{\circ} \mathrm{C}$ in an oven for 24 hours.

Loss on ignition is also given as weight \% of dry matter. After crushing, the sample was ignited at $860^{\circ} \mathrm{C}$ to constant weight (normally after 4 hours). The uncertainty of the double-determinations is less than $2 \%$ relative.

The water-content and loss on ignition were determined on all 900 samples.

The lime-content was determined on about 250 samples by titration. There may be an overestimation of the $\mathrm{CaCO}_{3}$-content caused by the presence of other carbonates which have consumed acid. The uncertainty of the determinations is about $2 \%$ relative.

When the sample is ignited the lime decomposes: $\mathrm{CaCO}_{3} \rightarrow \mathrm{CaO}+$ $\mathrm{CO}_{2}$ and the $\mathrm{CO}_{2}$-loss amounts to $44 \%$ by weight of the lime-content. The difference between the total loss on ignition and this $\mathrm{CO}_{2}$-loss is termed the reduced loss on ignition of the sample.

Water-content, loss on ignition and reduced loss on ignition are correlated excellently with the content of organic bound carbon in the sample. An example of this is seen in fig. 4 which includes a series of gyttjasamples from the boring Bendstrup 60.

Opal-content. The content of opal in a lake-sediment is chiefly derived from the diatoms. Besides the remaining organic production it gives a measure of the trophic state of the lake (HANSEN 1966). The content of opal was determined as the alkali-soluble part. 26 double-determinations were carried out, the results of which were unfortunately rather inaccurate.

The value of humification. The analytical methods correspond closely to that described by BAHNSON (1968).

The content of organic bound carbon was determined by combustion in an induction furnace (type Leco model 521). The generated $\mathrm{CO}_{2}$-mass is weighed after absorption in an ascarite tube. The $\mathrm{CO}_{2}$-content derived from the lime-content of the sample is subtracted and the organically bound $\mathrm{C}$ is indicated as weight $\%$ of dry matter.

The content of nitrogen was determined in the Geochemical Laboratory of the Geological Survey of Denmark (DGU), using the method of Dumas. The C- and N-determinations were carried out on 16 samples. 


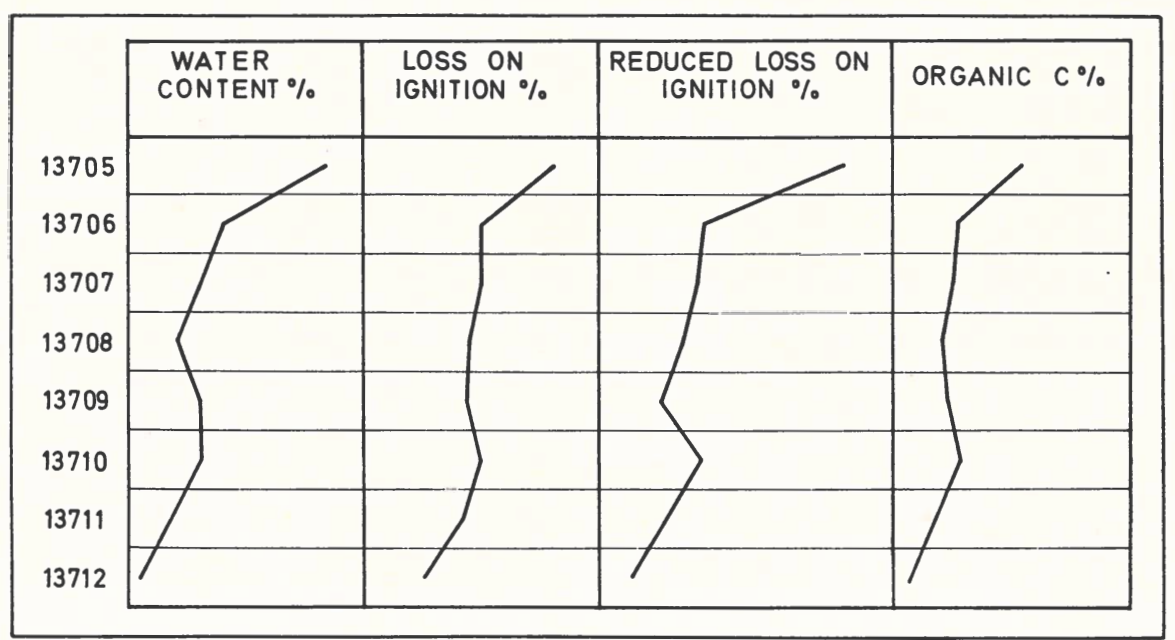

Fig. 4. Correlations between organic $\mathrm{C} \%$ and water-content, loss on ignition and reduced loss on ignition.

The contents of $\mathrm{Ca}, \mathrm{Al}, \mathrm{Ti}, \mathrm{K}, \mathrm{Si}, \mathrm{Fe}$ and $\mathrm{Mn}$ in the ignited remnants were determined by X-ray fluorescence on a Philips PW-1220 semiautomatic spectrograph. $\mathrm{Ca}, \mathrm{A} 1, \mathrm{Ti}, \mathrm{K}$, and $\mathrm{Si}$ were determined using a $\mathrm{Cr}$-target $\mathrm{X}$-ray tube, $\mathrm{Fe}$ and $\mathrm{Mn}$ with a W-target $\mathrm{X}$-ray tube.

Chemical analyses of 4 samples before and after the ignition were carried out in the Geochemical Laboratory of DGU.

The mineral content was investigated using a Philips X-ray diffractometer with $\mathrm{Cu}-\mathrm{K} \alpha$-radiation.

$X$-ray radiographs were taken of an intact core about $4 \mathrm{~m}$ long. The apparatus and method have been described by THIEDE and LARSEN (1971). 


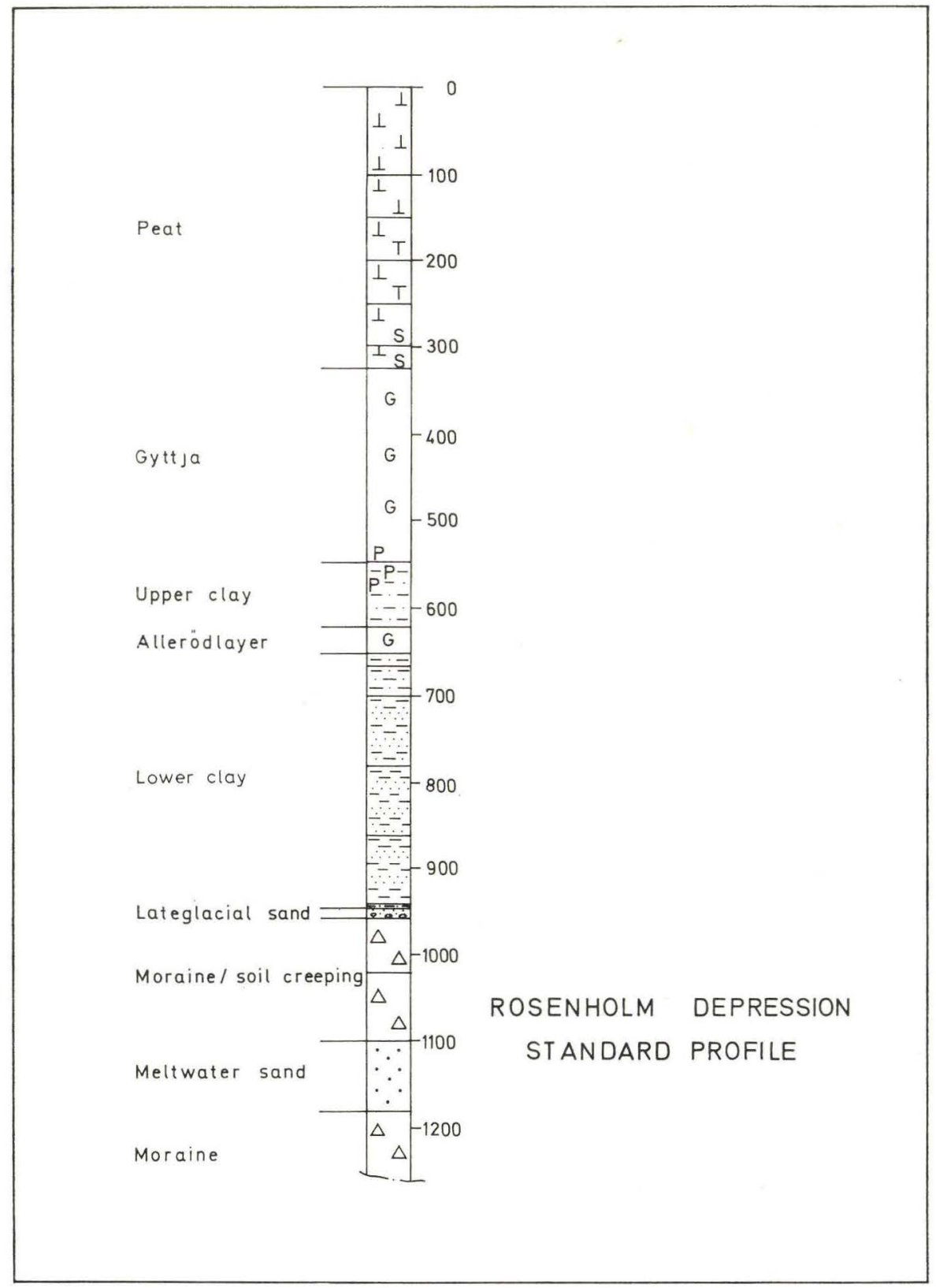

Fig. 5. 


\section{COMPOSITION OF THE SEQUENCE}

The drilled sequence included Lateglacial sand, clays and gyttja and Postglacial gyttja and peat. Only freshwater sediments were found. The borings made with the Hillersampler were normally terminated when the Lateglacial sand was reached. Using different boring-equipment (54 $\mathrm{mm}$ sampler, type Geonor), deeper cores could be obtained, and the contact with the underlying moraine could be reached. This boring was carried out close to boring Bendstrup 60-the deepest one in the Rosenholm depression which earlier had been drilled by the Hiller-sampler. The combined profile from this locality is shown in fig. 5 and is taken as an example of the sequence as it is widely developed in the Rosenholm depression. The boring was completed about $80 \mathrm{~cm}$ into a hard, grey moraine which contained $\mathrm{cm}$-large flints. Above this, coarse meltwatersand was found. The core-recovery was only about $25 \%$ because the sandlayers have a high water-content. Above the meltwatersand an approximately $11 / 2 \mathrm{~m}$ thick, fairly soft morainic formation was found, part of which (depth 1005-1025 cm below the peat-surface) is seen in the X-ray radiograph, photo No. 1. Traces of layering, which may be primary, are present.

Sтокноцм (1968) describes a soft moraine from the excavations for the Limfjord tunnel, which has a tendency to show layering, and which he interprets as having been sedimented from dead ice.

On the X-ray radiograph showing a part of the core from $1045-1065 \mathrm{~cm}$ (photo No. 2) a sandlayer occurs that increases in thickness from left to right. This layer was possibly washed into the basin from its nearby margin. After this it is thought that more slumping occured and that the $11 / 2 \mathrm{~m}$ of morainic material was derived from soil creep. The possibility that the layering results from the pressure of the drill-pipe cannot be totally excluded.

\section{Lateglacial sand:}

Photo No. 3 shows the transition between the assumed creeping soillayer and the Lateglacial fluvial material. The transition-layer which is about $8 \mathrm{~cm}$ thick consists of coarse sand with cm-large flints and limestone pebbles. The majority of the borings stopped shortly after penetrating this Lateglacial sandsurface, because of the difficulty of penetrating even thin layers of sand with the Hiller-sampler.

The topography of the sand-deposit is shown in fig. 6. The depths of the 


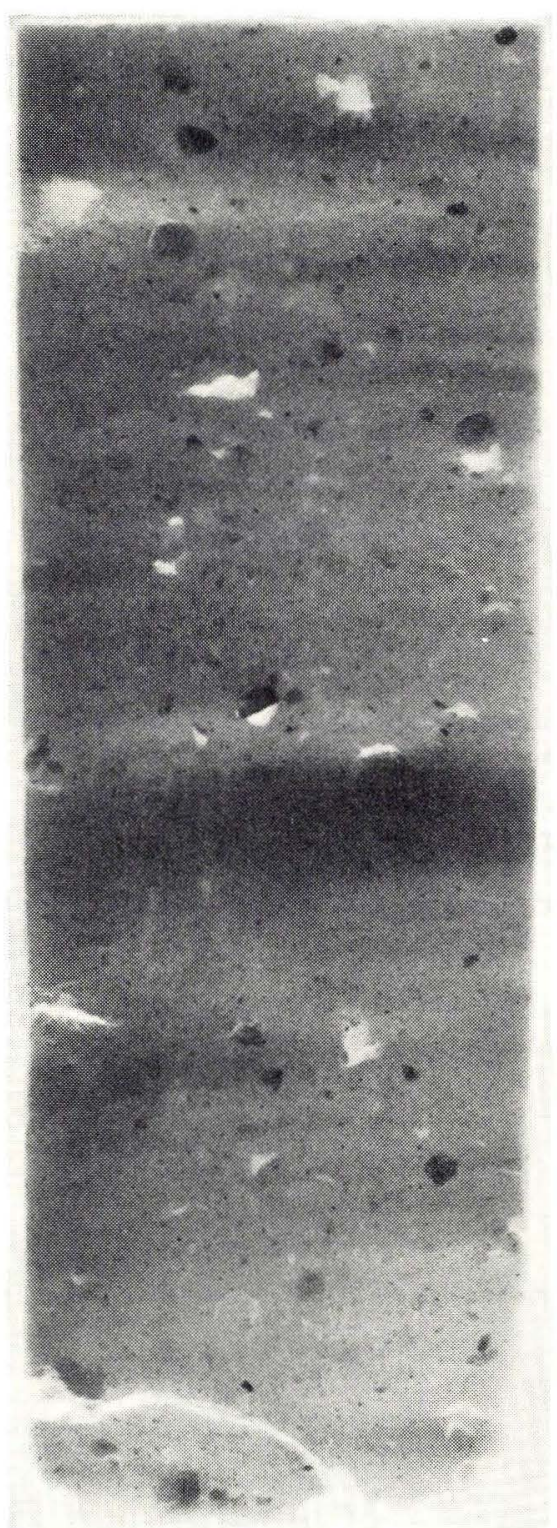

Photo No. 1. Creeping soil. X-ray radiograph. Depth $1005-1025 \mathrm{~cm}$ (below peat-surface).

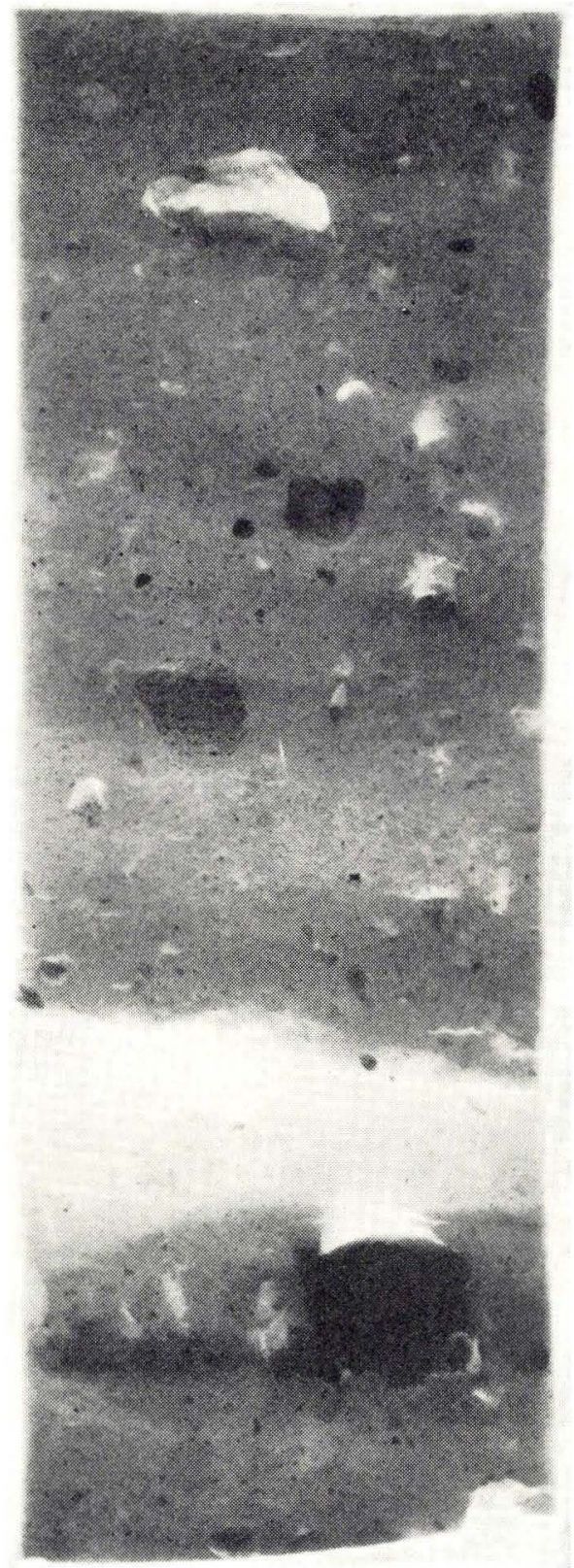

Photo No. 2. Outwash sand. X-ray radiograph. Depth 1045-1065 cm (below peat-surface). 


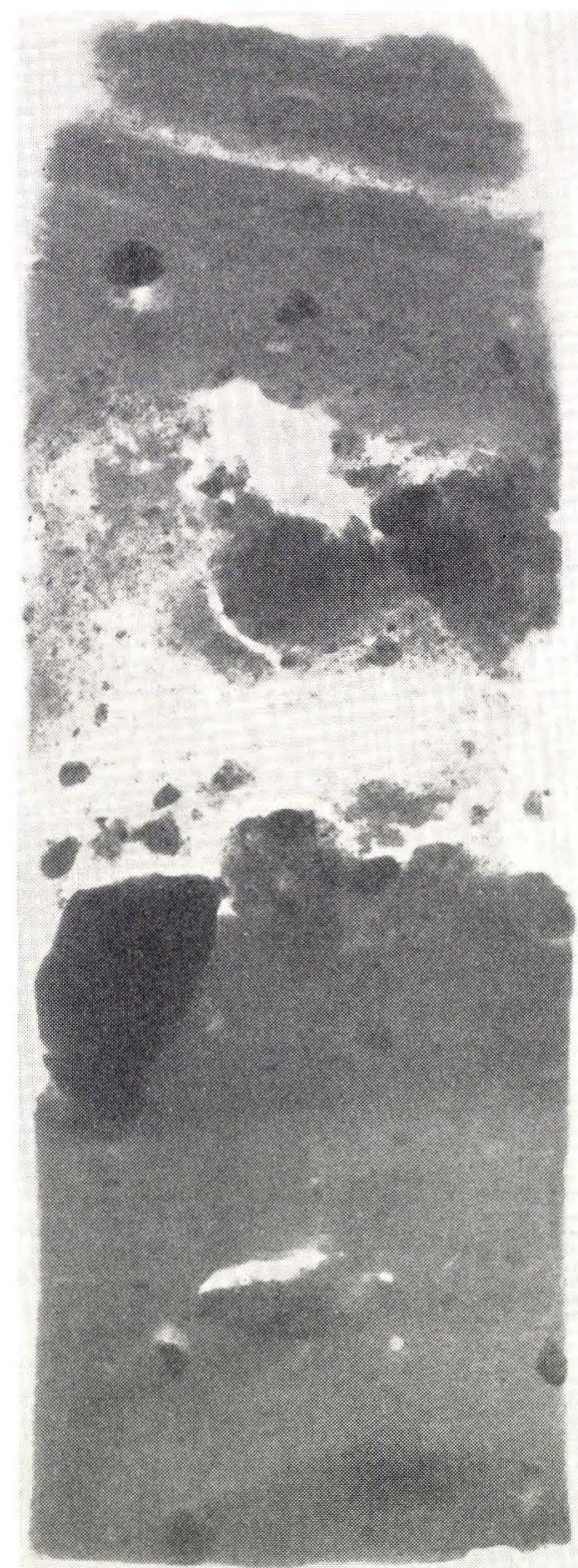

Photo No. 3. Transition between

creeping soil and Lateglacial sand.

X-ray radiograph. Depth $945-965 \mathrm{~cm}$

(below peat-surface). 


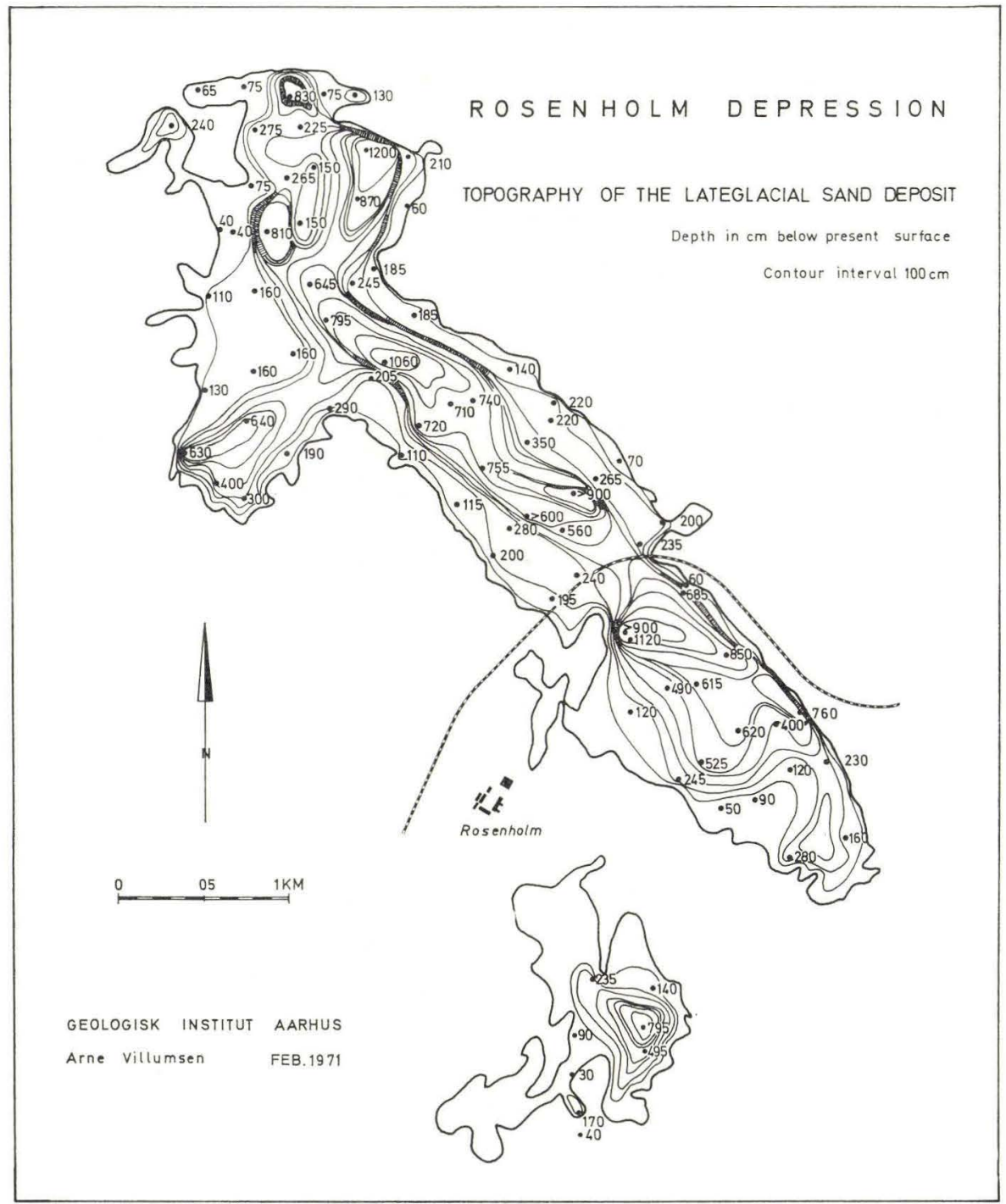

Fig. 6.

borings, indicated in $\mathrm{cm}$ below the peat-surface, vary a great deal. The bottom of the depression is dominated by several deep holes, arranged in a meandering course in the length-direction of the basin. The sides often have steep slopes. At several locations, for example where the railway crosses the depression, sand-barriers occur in the bottom of the basin. The meandering course and irregular bottom relief of the depression may indicate that the basin has a subglacial prehistory (tunnel valley). This is being investigated by further mapping of the surrounding area. 


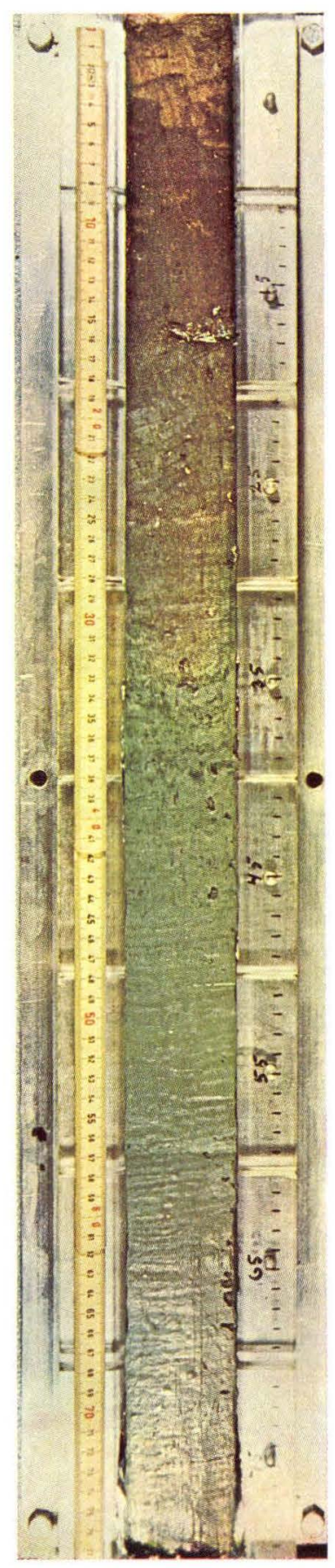

Photo No. 4. Upper clay Allerød-gyttja. Coresection, depth $625-705 \mathrm{~cm}$ below peatsurface. 
The lower clay:

Above the Lateglacial bottom-layer in the deepest borings (Nos. 49, 60 and 66-for location, see fig. 3) occurs an approximately $3 \mathrm{~m}$ thick rhytmically alternating deposit of clay and silt with subordinate sandlayers. The lower part of the series consists of mm-thick layers of silt and clay. The colour is grey and dark-grey. The thickness of the layers and the siltcontent decrease upwards. The upper part of the deposit which is seen at the bottom of photo No. 4 is chiefly composed of light steel-grey clay with a small amount of silt. The individual, rather thin, layers of clay, are separated at the top by fine organic, black bands. Further down-at a depth of 670 $705 \mathrm{~cm}$ - the dark layers become more and more indistinct, and they totally disappear at $705 \mathrm{~cm}$.

The upper part of the lower clay is also "varvig", which is seen on the X-ray radiograph from depth $689 \mathrm{~cm}$ to $672 \mathrm{~cm}$ (photo No. 5). The watercontent of the lower clay is about $25 \%$, the loss on ignition is from 6-8\%, and the lime-content is $10-15 \%$. The geological interpretation of the lower clay will be mentioned in the chapter concerning the upper clay.

The Allerød-layer:

In borings Nos. 49, 60 and 66 the lower clay is overlain by the so-called Allerød-layer which is found at 15 locations in the depression (fig. 7). In 10 of the remaining 12 borings the layer rests directly on the Lateglacial sandsurface, and is therefore probably incomplete. The two last borings, Nos. 35 and 37 , will be mentioned separately later on.

The layer, which in thickness varies from af few $\mathrm{cm}$ to about $3 / 4 \mathrm{~m}$ is probably of Allerød age (personal communication statsgeolog dr. phil. J. IVERSEN 1971). A great number of samples from the whole bog profile have been sent for pollen analysis to DGU but the results of this investigation are not yet available.

The Allerød-layer is found at several localities in the deeper parts of the Rosenholm depression (fig. 7). Lithologically the NW-stern part of the basin with an Allerød-gyttja can be distinguished from the SE-stern part where Allerød-soil and -peat are found and from the bog of Hornslet which has sphagnum-peat.

The Allerød-gyttja: On the top of photo No. 4 which includes the coresection from 625 to $705 \mathrm{~cm}$ the Allerød-gyttja can be seen which in this case is bluish-black with yellow burrows. In other places the colour is grey or yellow-grey. Photo No. 6 shows the X-ray-radiograph of the core from 640 to $655 \mathrm{~cm}$. Layering is absent, and the sample is richly fossiliferous with the fossils often showing indications of solution. The fauna (investigated by cand. scient. ANNE-Lise LyKKe ANDERSEN) is poor in species with the bivalve Pisidium sp. and the snails Lymnea sp. and Valvata sp. being dominant. 


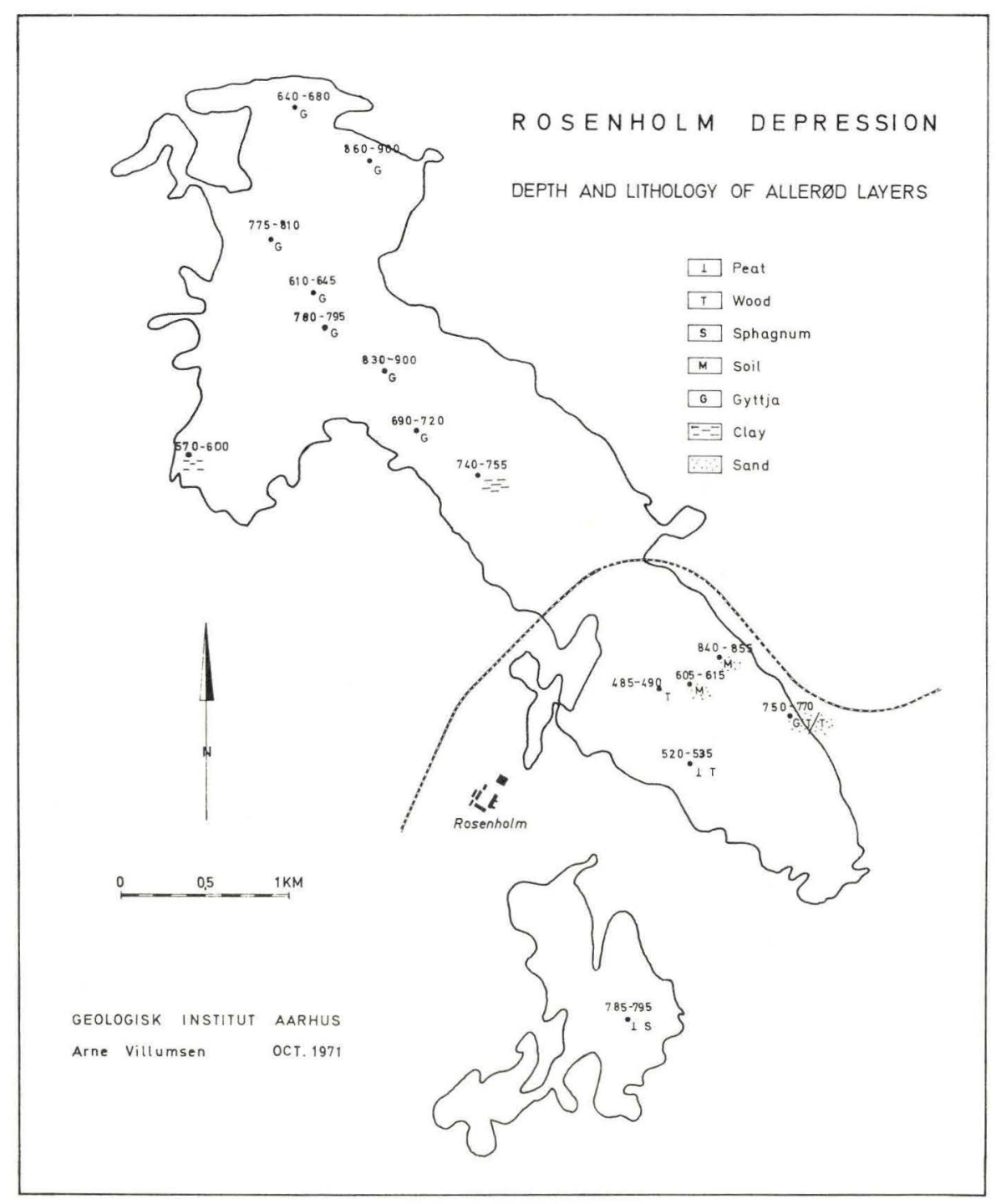

Fig. 7.

They are characteristic of desiccating water pools. All three species are able to dig themselves several $\mathrm{cm}$ into the bottom during the periods of very shallow water.

In addition to these three shallow-water forms some partly dissolved shells of Anodonta or Unio occur (see photo No. 4) which are normally found in somewhat deeper water.

The fact that the number of species is not high may indicate a special environment. The bluish-black colour of the gyttja is indicative of reducing 


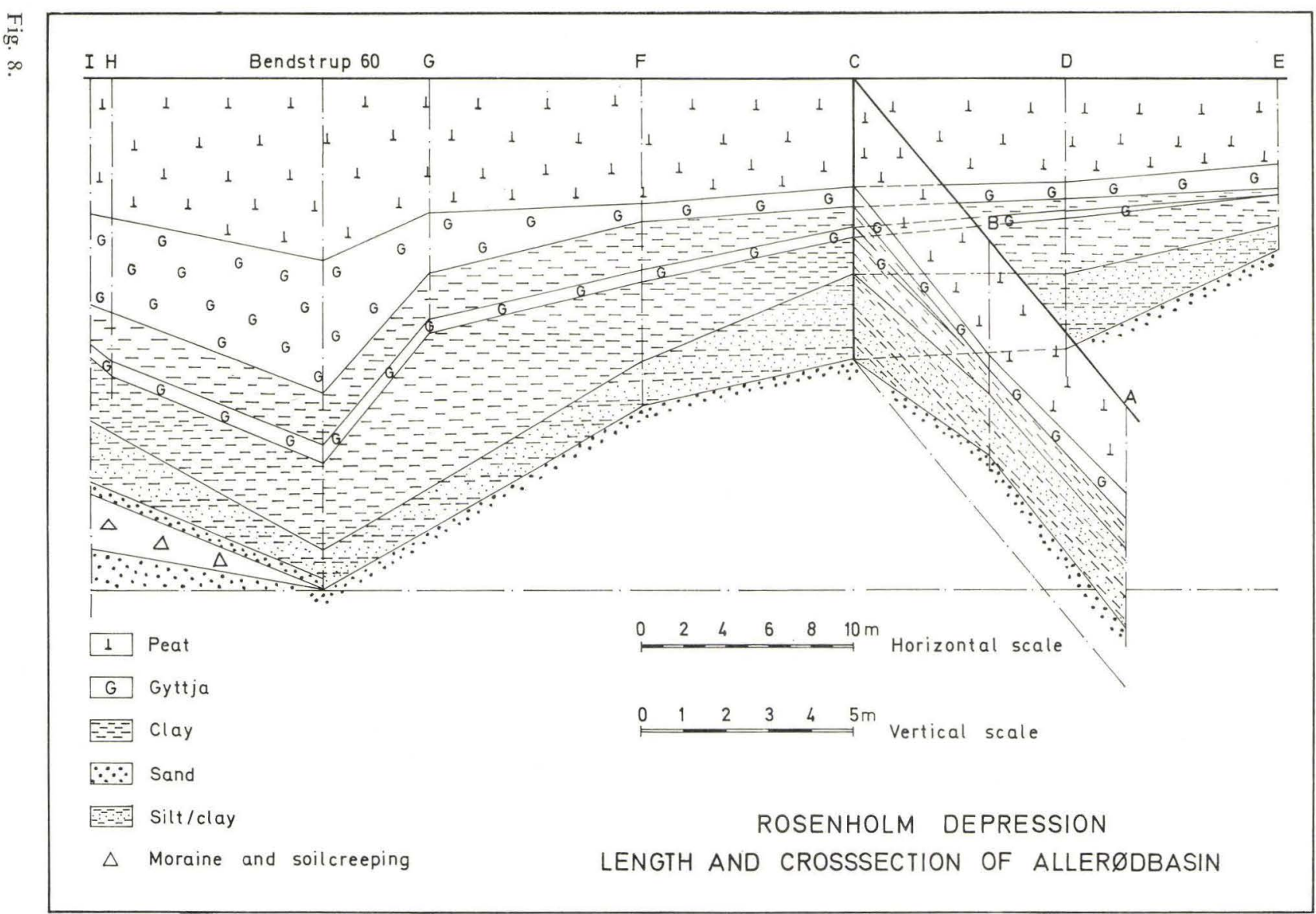


conditions. Mineralogical investigations of this layer showed a small content of pyrite.

The oxygen-supply was great enough for a narrow zone around the burrows to have been oxidized. Measurements of the recent Eh of this layer gave some of the lowest values in the depression (about $+100 \mathrm{mV}$ ). The water-content of the gyttja is about $120 \%$, the loss on ignition 16-18\%, and the lime-content $22 \%$ as an average.

The bluish-black Allerød-gyttja has been found at several localities in the depression, e.g. boring Bendstrup 60. In order to investigate its conditons of deposition further a series of additional borings were carried out in this area. It appeared that the Allerød-gyttja occurs in a narrow basin, about $100 \mathrm{~m}$ long, and that the layer thins towards the basin margins. The greatest thickness is found in the deep central part, where the gyttja is deposited under anaerobic conditions, as described above.

The elongate, somewhat curved form of the Allerød-basin may indicate that it is formed in a ligated part of the course of the Lateglacial meltwater-stream. The presence of curved tongues of land, which project just $\mathrm{N}$ of the basin, and the bottom-morphology of the depression (fig. 6) support this assumption. Nine extra borings were carried out (60 A- $60 \mathrm{I}$ ) around Bendstrup 60, and fig. 8 is produced from the field-observations showing a length- and crossprofile of the Allerød basin. The length-section strikes NW-SE, and the cross-section roughly N-S.

In the borings $\mathrm{G}, \mathrm{H}, \mathrm{I}$ and Bendstrup 60 the gyttja is bluish-black and towards the basin edge the colour changes to a light grey-brown. Burrows are ubiquitous in the gyttja.

Normally a gyttja will cover an area rather less than the lake in which it is deposited because the bankzone is too agitated for gyttja-formation. HANSEN (1966) stated that the water cover necessary for gyttja-formation to occur varies between several metres at an open coast to about $40 \mathrm{~cm}$ in quiet bays. It is striking that no traces of a lake borderzone are found in the Allerød basin at Bendstrup 60. In other places in the Rosenholm depression, e.g. in the boring Termestrup 35 (for location see fig. 3), burrows and fossils are found in the lower clay, i. e. just in the borderzone outside the area where the gyttja is formed.

In the boring Smedegrave 37 a fossiliferous clay was found occurring between a clay without shells. This fossiliferous layer may correspond to the border zone of an Allerød lake. At Bendstrup 60 burrows and fossils are exclusively found in the Allerød-gyttja, and there are no indications of fossils in borings just a few metres outside the gyttja-area. Therefore the gyttja must have been deposited in a quiet area, where the water depth in the shallowest part was about $40 \mathrm{~cm}$, or possibly less, which the fauna also indicates. 
The water-depth in the central part of this basin was probably a maximum of about $4 \mathrm{~m}$. Since the Allerød-layer in the deepest boring (Bendstrup 60) is found today at nearly $9 \mathrm{~m}$, and the lake-border at a depth of about $3 \mathrm{~m}$, greater depths may have been expected.

The uniformly sloping bottom, which can be followed from boring D over $\mathrm{C}$ and $\mathrm{F}$ to $\mathrm{G}$ is replaced between boring $\mathrm{G}$ and Bendstrup 60 by a steeper bottomslope which does not seem to fit into the picture of a relatively shallow lake with a soft, fairly plastic bottom sediment. Thickness and facies evidently indicate that the gyttja in boring 60 was the deepest deposit of the basin, but the steep bottomslope is most likely to have been caused by a later subsidence of the layers close to Bendstrup 60 . This subsidence may be a result of the melting of deadice in the substratum. The subsidence, which was about $2 \mathrm{~m}$ in total, occurred at a rather late time since the upper clay which overlies the Allerød-gyttja is in boring H, Bendstrup 60, G and $\mathrm{F}$, of about the same thickness, corresponding to a fairly horizontal bottom topography of the basin when the clay was deposited. During the following, probably Postglacial, gyttja-formation, a considerably thicker layer was deposited at Bendstrup 60 than has been found in the neighbouring borings. The subsidence of the Allerød-gyttja might therefore have taken place during Postglacial time, if the age of the superimposed gyttja is correct. As it is doubtful whether an ice-block of the dimensions in question could be stored cold in the substratum far into the Postglacial time, it can be assumed that the ice disappeared soon after the upper clay was deposited. After this the subsidence may have occurred at about the transition between Late- and Postglacial time.

In addition to this single basin several separated Allerød basins are found in the NW-stern part of the Rosenholm depression. The exact number is not known, but it is certain that not less than three existed. Besides the basin at Bendstrup 60, one exists at the boring Andi 66 where the Aller $\varnothing \mathrm{d}$ sedimentation must have taken place (see fig. 6) in a roughly circular basin surrounded by sand barriers. A few additional borings in this area indicate that subsidence of the Allerød-layer may have occurred. It can not be decided whether the large NW-SE deep area around Bendstrup 49, where the Allerød-gyttja is found in several places, was one basin or if it was subdivided into a series of small lake basins.

The water depth, determined by investigations of the Bendstrup 60 basin, unfortunately cannot be expected to be valid for the rest of the Allerød-occurrences, as the limnological conditions at different places in the depression have not been the same. Borings 35 and 37 have been mentioned as examples of a gyttja-free marginal zone, where the redimentation occurred under more agitated conditions than at Bendstrup 60. It is surprising to note that the Allerød-gyttja was not found in boring No. 56 in which the bottom-sand was not reached until a depth of $8.70 \mathrm{~m}$. The Allerød-layer may 
exists here but because of difficulties with the boring equipment no samples were obtained between 6.00 and $7.70 \mathrm{~m}$.

The Aller $\varnothing d$-mould and-peat: In the SE-stern part of the Rosenholm depression the Allerød-layer is found in 5 borings Nos. 5, 9, 15, 16 and 18 (see fig. 7). In every case the sediments in question differed from the gyttja found in the NW-stern part of the depression, and the layer rests directly on the sand-substratum. The greatest thickness $-20 \mathrm{~cm}$ - is found in boring No. 5 where a sandy layer of wood was found at the base below a woody gyttja. In borings 9 and $18,15 \mathrm{~cm}$ of peat rich in wood and $5 \mathrm{~cm}$ wood were found respectively. Borings 15 and 16 , both penetrated a $10 \mathrm{~cm}$ thick organic layer containing some sand. In all 5 borings the thickness of the layers and the content of wood indicate that the deposits were sedimented below a modest cover of water. The organic, sandy layer, which is found in borings 15 and 16 was presumably deposited on land, and is consequently termed "Allerød-mould" (HarTz 1912). In boring No. 79, $10 \mathrm{~cm}$ of sphagnumpeat, also of a presumed Allerød-age was found.

The sidimentation of the Rosenholm depression during Allerød-time was of 3 different types due to differences in the water-depth: the gyttja-facies of the NW-stern part is separated from the nearshore SE-part by the dominant sandbarrier at the railway-crossing.

Analogously the bog of Hornslet is separated from the SE-part by the Lateglacial sand-deposit. In the period following the Allerød-time the bog of Hornslet and the Rosenholm depression followed the same course of development. The area NW of the railway barrier still differed from the remaining depression in the subsequent period, and not until Postglacial time did the depression as a whole act as a sedimentological unit.

\section{The upper clay:}

The upper clay which overlies the Allerød-gyttja is found only in the NWpart of the Rosenholm depression. It closely resembles the lower clay in many ways: both have roughly the same colour, about the same lime-content and neither contain macroscopic fossils. Nevertheless characteristic differences exist: the water-content and loss on ignition of the upper clay shows that its organic content is greater than in the lower clay, especially in its upper part. The reduced loss on ignition, which just above the Allerød-gyttja is practically zero, increases gradually upwards in the clay-layer, as a result of plantfragments which occur concentrated in thin layers in the upper part.

The upper clay is dark-grey to bluish-grey and besides silt it contains a few cm-large stones, some of which are seen at the bottom of the X-ray radiograph from 588 to $607 \mathrm{~cm}$ (photo No. 7). The content of silt seems to have been supplied from the basin-edges, as it is especially found near the margin. On photo No. 7 some layering can be seen but less distinct 


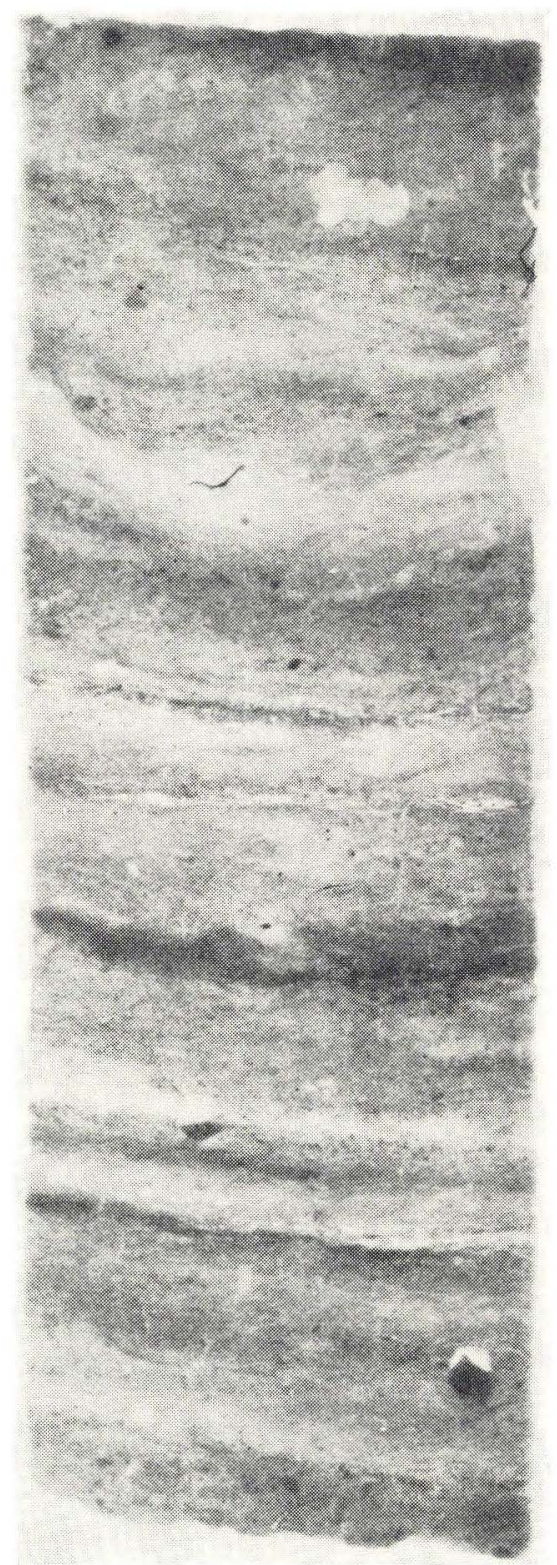

Photo No. 7. Upper clay. X-ray radiograph. Depth 588-607 cm below peat-surface. 
than in the lower clay. The water-content is seldom higher than $80 \%$, the loss on ignition is between 5 and $12 \%$, and the lime-content is about $10 \%$.

The rhythmically alternating series of clay and silt (lower- and upper clay), which surround the Allerød-gyttja have been termed "varvig". HANSEN (1940) states, that a sediment should only be called "varvig", if the individual layers succeed in climatic-conditioned annual rhytms. The theory of varves was developed by DE GEER who thought that changes in the material-supply of the meltwater rivers were the only reason for their formation (HANSEN 1940). True varving can therefore hardly be possible for the lower and upper clay of the Rosenholm depression, since the ice must have been too far away for variations in the meltwater-supply to be registered. HANSEN (1940) points out variations in precipitation as the reason why basins in clay-areas initially become filled with layered clay, by which the well-known profile consisting of Dryas-clay, Allerød-gyttja and Dryasclay is formed. The lower and upper clay are therefore presumably outwashclay which are evidence of the local state of precipitation.

The absence of fossils and the moderate content of organic material indicate a cold climate interrupted by the Allerød-oscillation. No signs of a Bølling-oscillation were found in the Rosenholm depression. The variations in the material of the upper clay resemble those of the lower clay but the separation of the individual layers does not seem to be quite as clear-cut as in the upper clay (see photo No. 7). This can be seen in connection with the slightly increasing content of organic matter in the upper clay-assuming that organic activity is responsible for the slight disturbence of the layering. The gyttja-which occurs above the upper clay-shows no signs of primary layering.

\section{The gyttja:}

One of the most widespread types of sediment in the Rosenholm depression is a whitish-grey or yellow, finegrained, diatomeous, calcareous gyttja with shells of snails and bivalves, plus ostracods and a few fish-scales. The content of organic matter in the gyttja is considerable and increases upwards in the series of layers. The water-content varies from about $100 \%$ to $600 \%$, with an average about $350 \%$. The loss on ignition increases gradually upwards in the gyttja, reaching about $45 \%$ in the upper parts, where plant-debris and roots in a vertical position are often present. The lime-content is high, in some cases up to $90 \%$.

The fauna, which includes Bithynia tentaculata, Valvata sp. and Pisidium sp. seems to indicate quiet conditions of sedimentation under a watercover of less than $10 \mathrm{~m}$. The gyttja is found in the bog of Hornslet and in the Rosenholm depression on both sides of the railway-barrier (fig. 9). Locally it reaches a thickness of about $4 \mathrm{~m}$. The gyttja-sedimentation occurred over most of the depression. In many cases the gyttja is found 


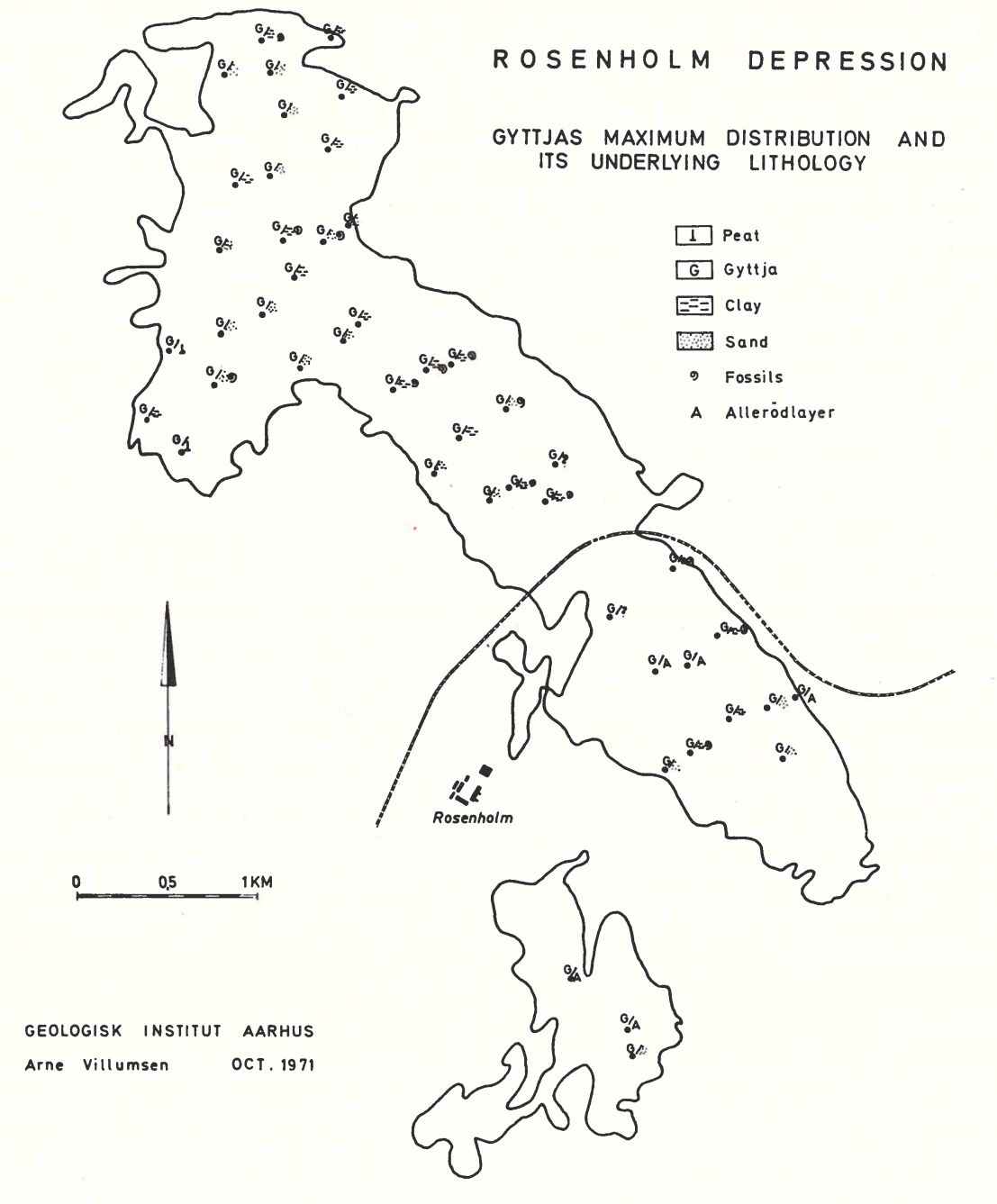

Fig. 9.

directly above the Lateglacial sand-deposit, especially in the flat levels nearshore or in the vicinity of the barriers. In 8 borings ( 7 in the NW-stern part, 1 in the SE-part) the gyttja is lying directly on the unfossiliferous upper clay (cf. the standardprofile, fig. 5).

In 10 borings ( 7 in the NW-part, 3 in the SE-part) a fossiliferous clay or clay-gyttja is found, which is included in the opening phase of the gyttja sedimentation. The deposit, of which the water-content and lime-content rapidly increases to values only a little less than in the lower part of gyttja, 
is found in the 7 borings in the NW-part between the upper clay and the gyttja.

In the SE-part of the depression, where the lower clay has only been found in one single boring (No. 7) the fossiliferous clay is found either directly on the sand-substratum (No. 21) or just above the Allerød-layer (Nos. 9 and 15). In places where the fossiliferous clay was not found the gyttja directly follows the Allerød-layer. In the bog of Hornslet the Allerød-layer in the same way is overlain by the gyttja.

The opening of the gyttja-sedimentation thus can be said roughly to have proceeded differently in the two basins, which are separated by the railwaybarrier. In the $N W$-stern area the gyttja formation starts either directly on the un-fossiliferous upper clay or on the fossiliferous clay-deposit. In the $S E$-stern area and the bog of Hornslet where the upper clay, with one exception, is not encountered the gyttja at some places is lying directly on the Allerød-layer. At other places the fossiliferous layer of clay lies directly on the Allerød-gyttja.

The gyttja-deposition proper seems to have developed in the same way in the depression as a whole as no macroscopic differences can be indicated. The determinations of water-content, loss on ignition and lime-content also indicate that the whole Rosenholm depression roughly followed the same pattern as the gyttja sedimentation continued.

The results from boring Bendstrup 60 (fig. 10) can be taken as an example of this: the graphs for water-content, loss on ignition and the reduced loss on ignition show that the content of organic matter in the lower $1 \frac{1 / 2}{2}$ of the gyttja increases gradually to a maximum-value of $450 \%$ where the colour of the gyttja is darkest. Above this a minimum occurs before the organic content once more increases in the upper part of the gyttja. The graph for lime-content shows a characteristic curve with two peaks. The lower peak (about $68 \%$ ) occurs where the organic content of the gyttja is steadily increasing. The lime-content after this drops and reaches its lowest value (ca. $52 \%$ ) at that level where the organic content is greatest. In the upper part of the lime-graph high values are reached once more (up to $62 \%$ ) where the organic content passes its minimum, before the lime-content drops abruptly and finally disappears at the transition to the peat. This relationship is found in most of the deep borings in the depression (16 cases in total), but at some localities exceptions are found:

Occasionally the organic- and lime-contents reach maxima together. In other cases the organic content increases uniformly throughout the series of layers. In fig. 11 the extension of the area where the largest organic content corresponds to the lowest content of lime is indicated. The combination organic max.-lime min. is found in the deepest central part of the depression, while the other possibilities are met with nearer to the basin margins. The lime-content of the gyttja is derived by transport in solution from the sur- 


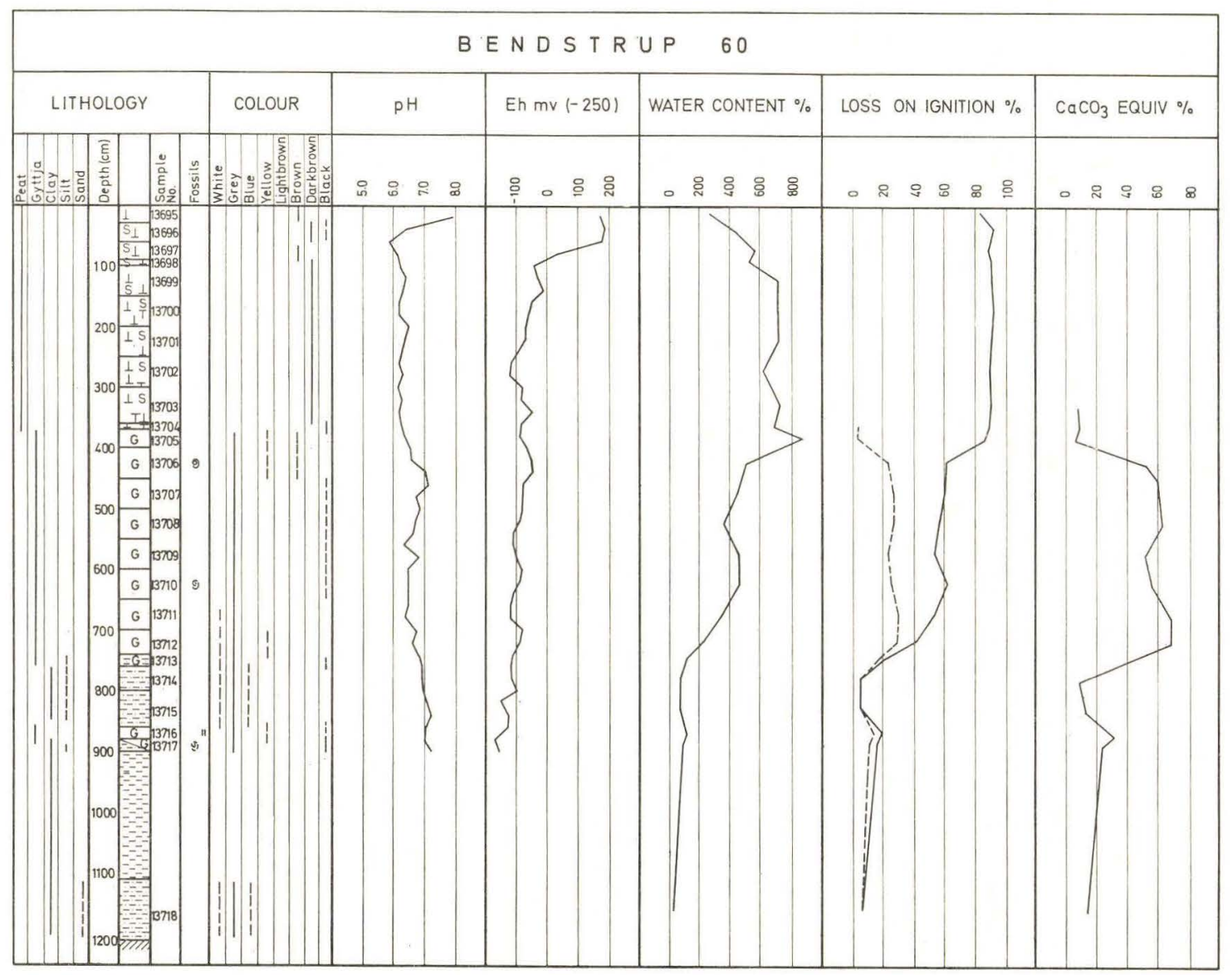

Fig. 10. Profilediagram. Lithology: Full line indicates chief component; depth in $\mathrm{cm}$ below peat-surface; explanation of lithological signs, see fig. 9; total loss on ignition with full line, $\mathrm{CO}_{2}$-loss from carbonates: dashed lines. (Reduced loss on ignition $=$ difference between full and dashed lines).

rounding moraine-landscape (CHRISTENSEN 1962). The sedimentation on the lakefloor takes place either directly or by the intervention of plants and animals (WESENBERG-LUND 1901).

The sudden decrease in the lime-content in the bottom sediments may be caused either by a solution of lime already deposited on the lake-floor, or be due to a decrease in the rate of lime-sedimentation.

It can be assumed that a solution of already deposited lime can occur if the lake suddenly recieves an abundant supply of acid water, e. g. by draining of one or more of the bogs in the surrounding area. It is difficult to determine the validity of this suggestion. The borings in which the limedecrease is observed (fig. 11) do not seem to be distributed around a possible 


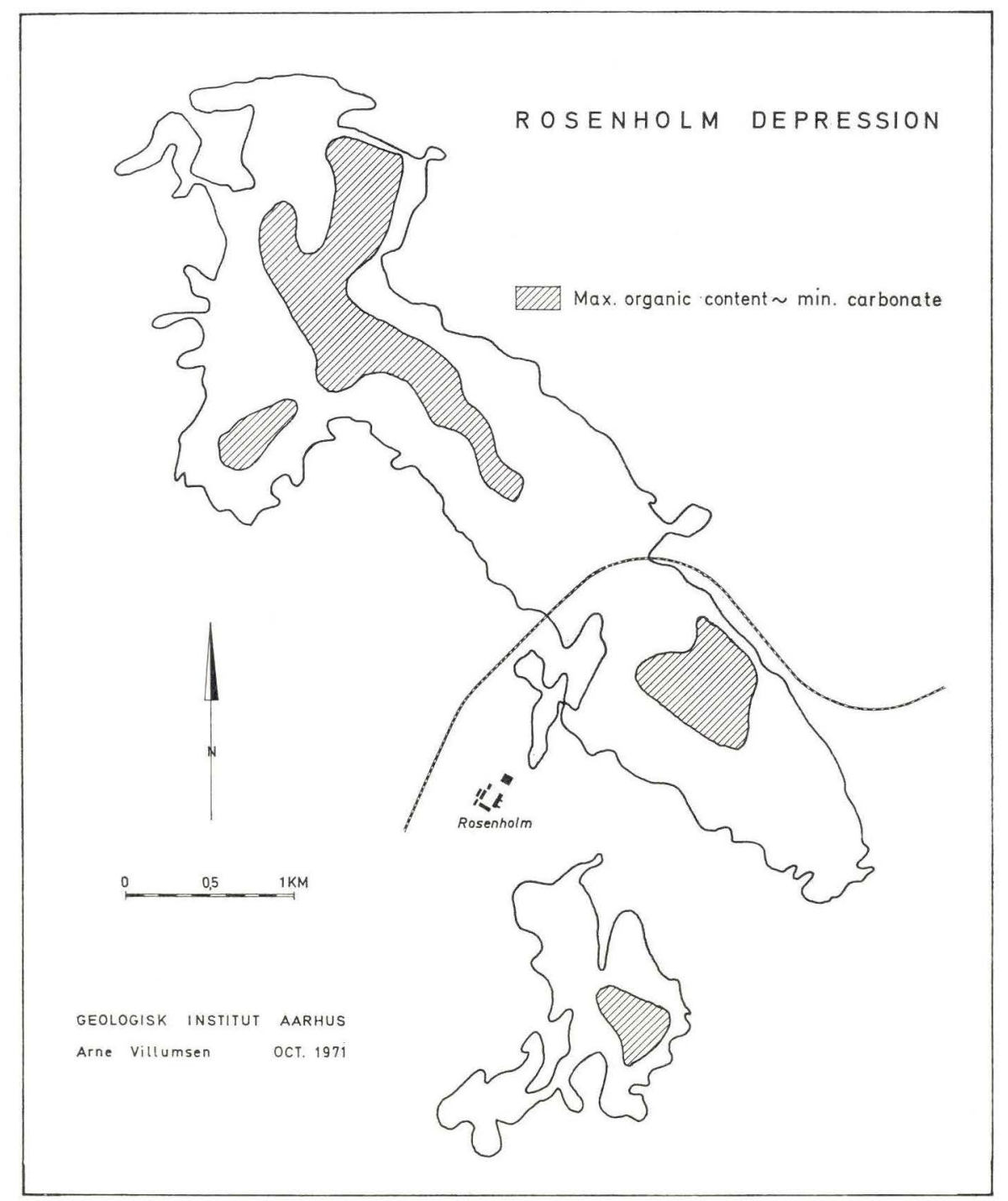

Fig. 11 .

channel for acid-water supply. The decrease in lime-content would be expected to be greatest at that place where the acid water entered the lake, and diminish in all directions. The distribution of the lime-minimum does not seem to indicate such a systematic variation. Therefore it is not suggested that the decrease in lime-content is a solution phenomenon.

Alternatively the lime-minimum could be due to a diminution in the deposition of lime on the lake-floor. The lime, which benifits the gyttja, is supplied to the lake from the surrounding calcareous moraine. Variations 3* 
in the rate of supply will be registered rapidly in the bottom sediments of the lake.

The interglacial lake-deposit at Hollerup provides an excellent example of how the geochemical state in the surrounding area controls the composition of the lake-sediment (ANDERSEN 1966 and 1969). In the Hollerup-lake siliceous gyttja was deposited above a calcareous gyttja when the lime-content in the surroundings was used up.

If the conditions in the Rosenholm depression correspond directly to those of the Hollerup-lake an increasing lime-content in the gyttja would not occur after the lime minimum. Therefore the moraine must have been able to supply the necessary amount of lime during the whole gyttja sedimentation, but either the rate of sedimentation of other components in the lake proper was greater for a period, so that the lime-minimum occurs as a result of "dilution", or the transport of the lime in solution was restrained.

As the rate of sedimentation is not known (partly because of lack of age dates) the first possibility will not be further discussed. If the lime-decrease is interpreted as having been caused by a reduced transport of lime to the lake, this occurred when the organic activity of the lake was at a maximum. The organic productivity of the lake is dependent to some extent on the climate, and the maximum in organic matter may therefore correspond to a warmer period during which the vegetable life on land flourished. Hence it is concluded that an increased plantcover on land was able to limit the transport of lime in solution to the lake, the bottom-sediments of which were correspondingly poor in lime.

It may be objected that an increased plant-cover on land simply increases the solution of lime, and it is thus curious that less lime is removed from the moraine. This cannot be discussed profitably without information about the drainage capacity.

The organic maximum of the gyttja can thus be interpreted, with some reservations, as a result of a short climatic improvement. This warmer period was followed by a deterioration in climate which is indicated by a decrease in water-content and reduced loss on ignition. At the same time the gyttja recieved an increased lime-supply from the moraine corresponding to poorer conditions for the plant-cover on land.

Together with the climate the geochemical state of the surrounding area greatly influences the composition of a lake sediment as was mentioned earlier with the Hollerup-lake as an example. The geochemistry further influences the content of nutrients of the lake which, analogous to the lime, are supplied in solution.

All chemical elements, which in one way or another are requirements for the development of the organic activity, should be considered as nutrients. Normally the most important will be phosphorus and nitrogen, which especially influence planktonic life (HANSEN 1966), but in special cases other ele- 
ments can also be of importance. The nutrientconditions (trophy-state) of a fossil lake can be determined by investigations of its biogenic production. Hansen (1966) states that the ratio:

$$
\frac{\text { lime }+ \text { opal }}{\text { lime }+ \text { opal }+ \text { minerogenic matter }}
$$

gives an expression of the trophy-state of the lake. In this way eutrophic lakes (rich in nutrients) can be distinguished from oligotrophic lakes (poor in nutrients). $\mathrm{CO}_{2}$ is consumed by plant-photosynthesis and lime can be sedimented on the leaves, from where it either falls on the lake-floor in rough weather or, remaining on the leaves or in the stem, is supplied to the bottom when the plant dies (WESENBERG-Lund 1901). The opal chiefly originates from the diatom content of the lake. It was earlier mentioned that the opalcontent was not determined in the samples from the Rosenholm depression sufficiently precisely, but as the lime-content in the gyttja is normally fairly high the trophy measured will only be influenced to a small degree by the content of opal, which on average lies below $10 \%$.

Based on the lime-quantity it can therefore be stated that the Rosenholm depression was an eutrophic lake in the period during the gyttja-sedimentation.

Investigations of the $\mathrm{C} / \mathrm{N}$-ratio of the gyttja, however, indicate that a bipartite development of sedimentation occurred which presumably took place on either side of the railway-barrier. Fig. 12 shows two gyttja-profiles, one from the SE-part of the depression (Mørke Kær 5), and one from the NW-part (Bendstrup 60). It appears that in the NW-stern part of the depression the variations in the $\mathrm{C} / \mathrm{N}$-ratio are so small that the gyttja-sedimentation may be assumed to have taken place almost without changes in the humus state. The $\mathrm{C} / \mathrm{N}$-ratio of about 10 classifies the bottom-sediment as a gyttja (HANSEN 1961). In the upper part of the profile just below the peat, the content of humus increases slightly (to $\mathrm{C} / \mathrm{N}=12$ ) so that the borderline between gyttja and dy (at $\mathrm{C} / \mathrm{N}=10$ ) is passed. In the SE-part of the depression $\mathrm{C} / \mathrm{N}$-values are found which partly lie considerably higher and partly show greater variations than found in the NW-part. The profile includes, as shown by the lithological column, both the Allerød-layer and the clay-gyttja above. The $\mathrm{C} / \mathrm{N}$-ratio of the upper four samples varies between 16 and 20. Below this the values increase greatly (to 46 in the lower-most sample, which is a woody Allerød-gyttja with some sand). Thus the $\mathrm{C} / \mathrm{N}$-ratio shows that the SE-part of the depression has been richer in humus (more dystrophic) than the NW-part. The bottom-sediment is dy or tyrfopel.

The variations in the $\mathrm{C} / \mathrm{N}$-ratio throughout the profile (Mørke Kær 5) are great. It is difficult, based on the few measurements available, to decide whether the differences are primary or a result of later transformations. 


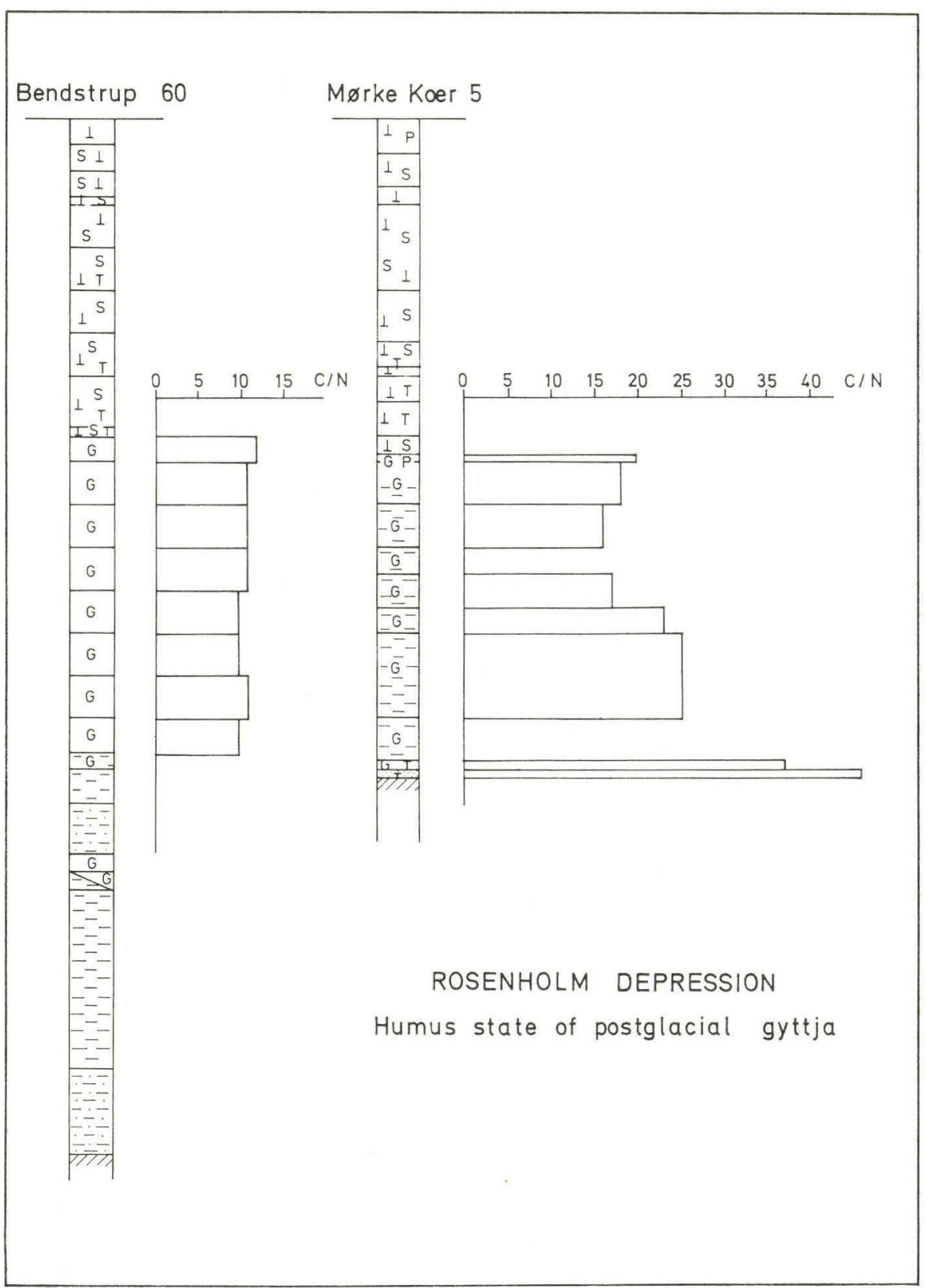

Fig. 12. 


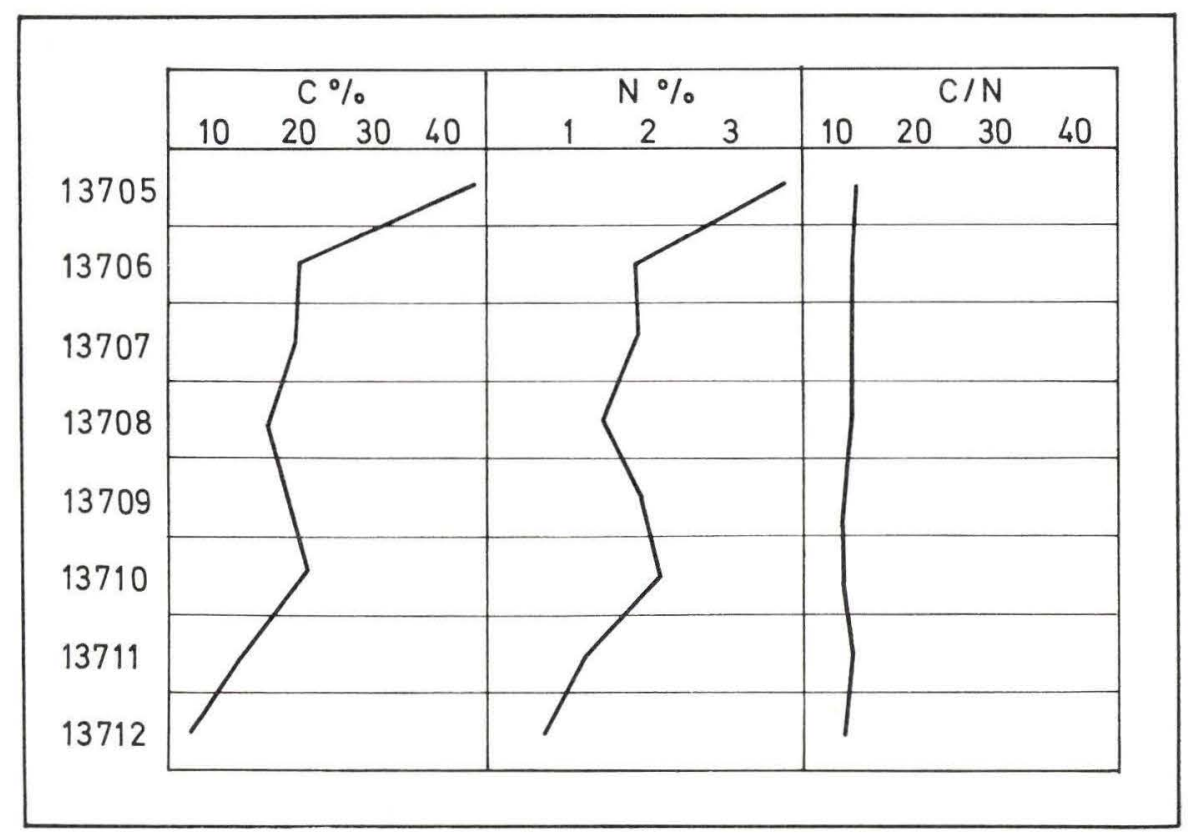

Fig. 13. Gyttja-profile from Bendstrup 60.

The $\mathrm{C} / \mathrm{N}$-values in the two lowest samples in boring Mørke Kær 5 (sample Nos. 12017 and 12018) are roughly as high as for peat, namely 46-52, (HANSEN 1959). The content of wood may be responsible for the high $\mathrm{C} / \mathrm{N}$ level, but there is another possibility: figs. 13 and 14 show the distribution of the $\mathrm{C}$ - and $\mathrm{N}$-content in the two borings. It appears that the $\mathrm{C}$-content in boring 60 and in boring 5 varies in roughly the same manner, and that the values in the two borings are of the same order of magnitude.

The content of nitrogen is lowest in boring No. 5 and through the profile it decreases from about $2 \%$ in the upper part to $0.2 \%$ in the lower two samples. In boring 60 the $\mathrm{N}$-content varies in the same manner as the carbon. The highest $\mathrm{C} / \mathrm{N}$-ratios thus occur because of a decreasing content of nitrogen in the lower parts of the series. The possibility that this difference is primary cannot of course be excluded, but as the nitrogen-content decreases with depth in the profile, the $\mathrm{C} / \mathrm{N}$-ratios may presumably be high because of later loss of nitrogen from the deposit. The differences between the $\mathrm{C} / \mathrm{N}$ values in the two borings are so large that there can be little doubt that they chiefly reflect syngenetic differences: The NW-part of the Rosenholm depression was an eutrophic gyttja-lake, while the SE-part was a nutrious, dystrophic lake with a dy or a tyrfopel bottom sediment. 


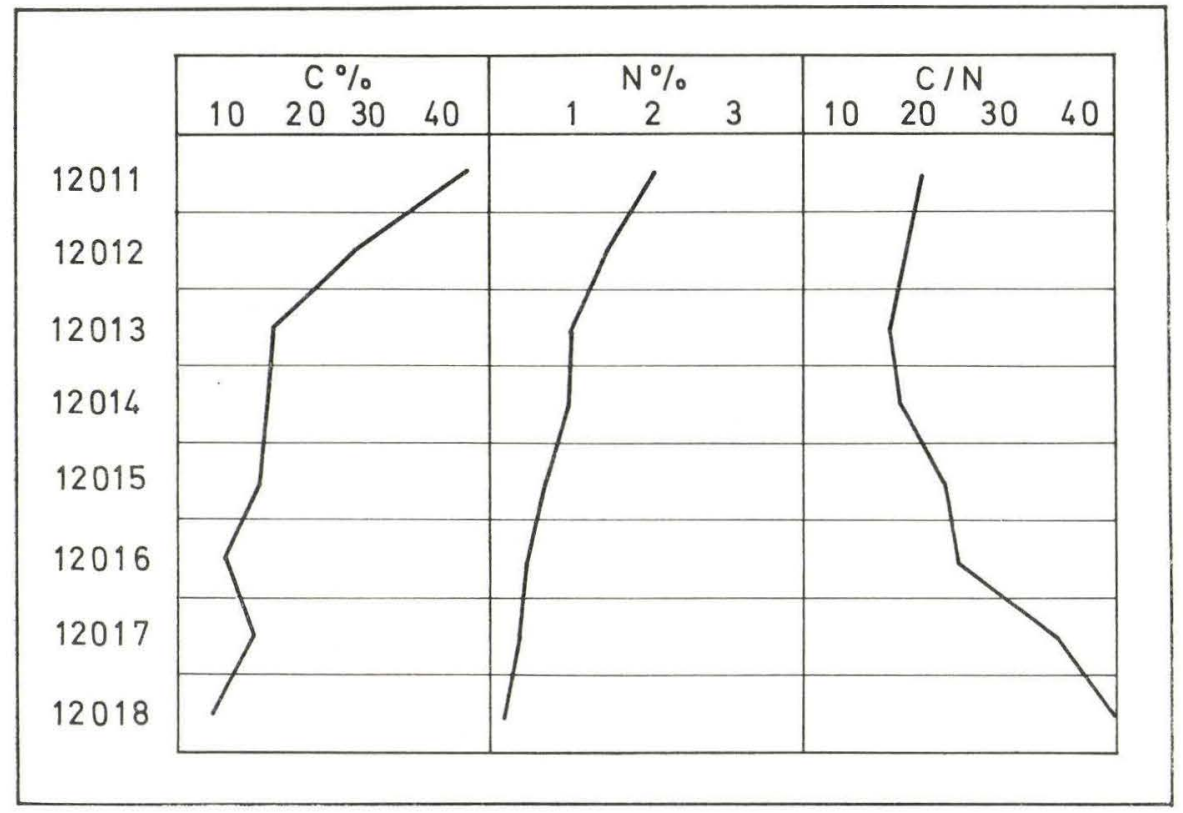

Fig. 14. Gyttja-profile from Mørke Kær 5.

The boundary between the gyttia and the peat:

The gyttja-formation in the NW-part and the dy-sedimentation in the SE-part of the depression took place in a lake with an open water surface. The gyttja is followed by peat, which, starting from the flanks of the depression, eventually covered the whole basin. The lowest part of the peat is in some places sphagnum-like corresponding to a spreading growth over the earlier lake surface. On the flanks the overgrowth started while the gyttja sedimentation continued in the deeper central parts. In the borings 36, 42 and 51 (fig. 15) indications are found that sphagnum-like floating bogs have extended from the basin edge some distance out into the lake. In boring 42 one layer of gyttja is found a short distance up into the peat, but in Nos. 36 and 51 more layers separated by sphagnum-like peat were found. Equivalent floating bogs were found in the bog of Aamosen and described by TroelsSмITH (1951), who relates them to variations of the waterlevel in the lake. (Under the field-description of the peat-material the term "Sphagnum-like" was used for peat having a high content of moss or a network of thin roots. This type of peat has a considerable water-content and loss on ignition. The composition of the plant material has not been investigated further). 


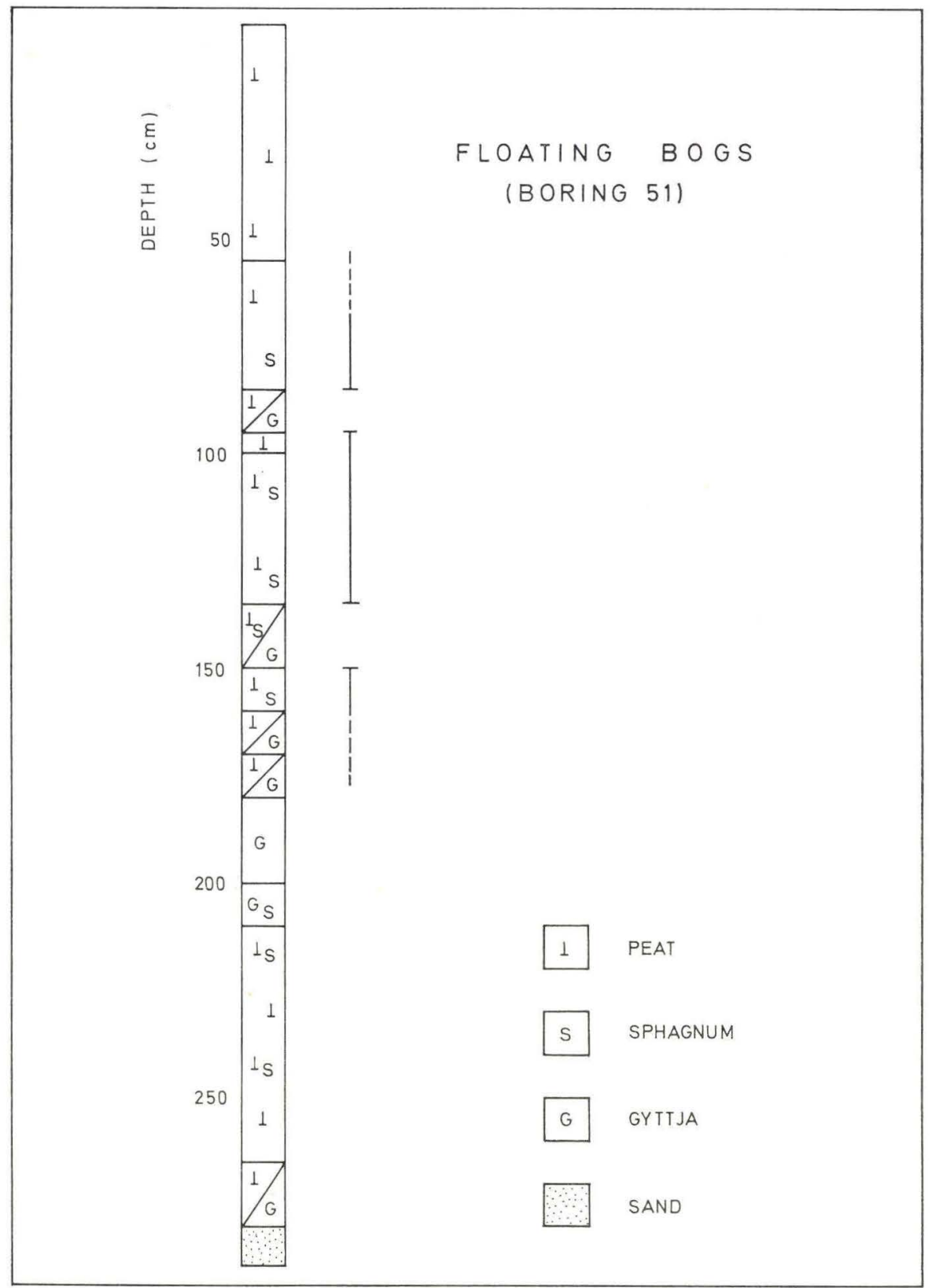

Fig. 15. Floating bogs indicated by vertical lines to the right of the lithological column. 


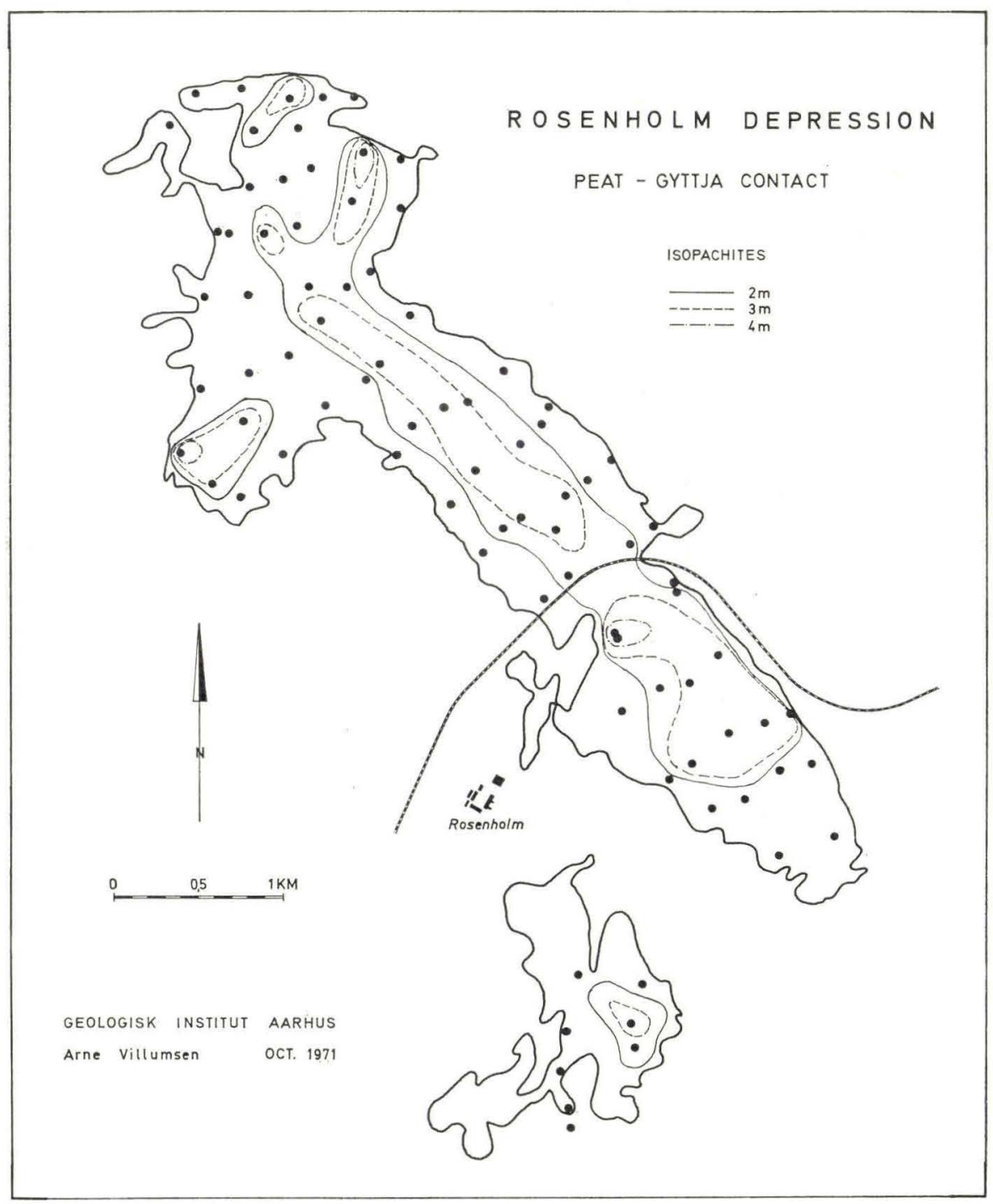

Fig. 16.

The peat:

The youngest sediment of the Rosenholm depression is the mappable peat and the total area covered by peat demarcates the depression as a unit. During the period from Allerød until the Postglacial gyttja-sedimentation was terminated, the railway barrier had separated the depression into two areas. The role of the barrier as a basin-divider seems to have ceased at the beginning of the peat-formation. Peat was deposited all over the basin which at the deepest places reached a thickness of about $4 \mathrm{~m}$. Fig. 16 shows an 


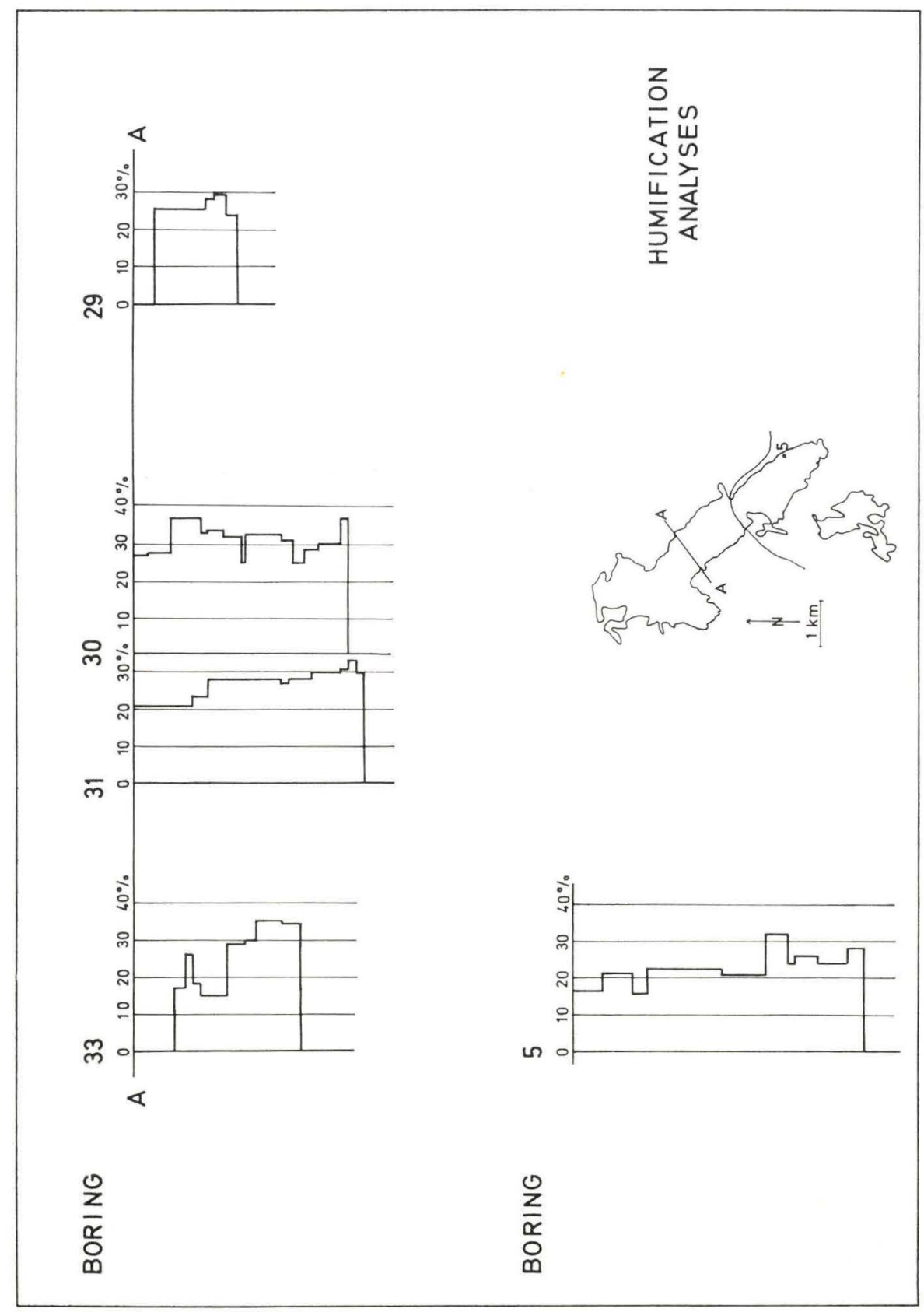

Fig. 17. Degree of humification shown in $\%$ on the abscis. 
isopach-representation of the peat thickness. The isopachs closely reflect the deep parts of the depression which had developed in Lateglacial time. The peat everywhere overlies the gyttja in the deepest parts of the basin, and in the marginal areas or at the barriers the peat rests directly on the sandsubstratum. In a few places sand barriers penetrate the recent peatcover as islands. A water-content of ca. $700 \%$ for the pure peat underlines, together with a loss on ignition of more than $70 \%$, the very high organic content. Sandsupply from the basin edges is clearly registered in the watercontent and loss on ignition. The lime-content disappeared at the transition from gyttja to peat. The contact with the gyttja is sometimes marked by a sphagnum-like layer, but often the lower part of the peat contains a certain amount of wood. At several locations larger wood fragments occur and in a few cases well-preserved oaktrunks are found.

The transformation to peat of the plant material is influenced by variations in climate and waterlevel. In periods with a moist climate the oxygen-supply is restricted and the peat will be light in colour with well-preserved plantfragments. A drier climate will allow the oxygen to totally alter the plant material to an amorphous dark substance. (GodwIN 1954, TEICHMÜLleR and TEICHMÜLLER 1967).

Investigations of the degree of darkness in colour (the degree of humification) have been carried out on a profile located at a place in the depression where variations in the waterlevel are assumed to have been registered very quickly (fig. 17). Below the profile the results of an analysis of humification carried out on the peat in boring No. 5 are indicated. The degree of humification varies between 15 and $37 \%$, but the differences cannot be followed through the cross-section with any reasonable certainty. The highest values are generally reached in the lower part of the peat. The climatic changes, which are registered by the analysis of humification in the raised peat-bog of Fuglsø (BAHnson 1968), thus cannot be traced in the Rosenholm depression which lies in a low terrain and recieves water from a large surrounding area. Small variations in the amount of precipitation therefore will easily be hidden, only the greatest differences being registered.

The low values of humification (about half as large as for the bog of Fugls $\varnothing$ ) indicate that the peat has permanently had a considerable watercontent which has prevented the oxygen-admission. Analysis of humification of peat from low-lying bogs therefore seems to be unreliable for the elucidation of climatic variations. 


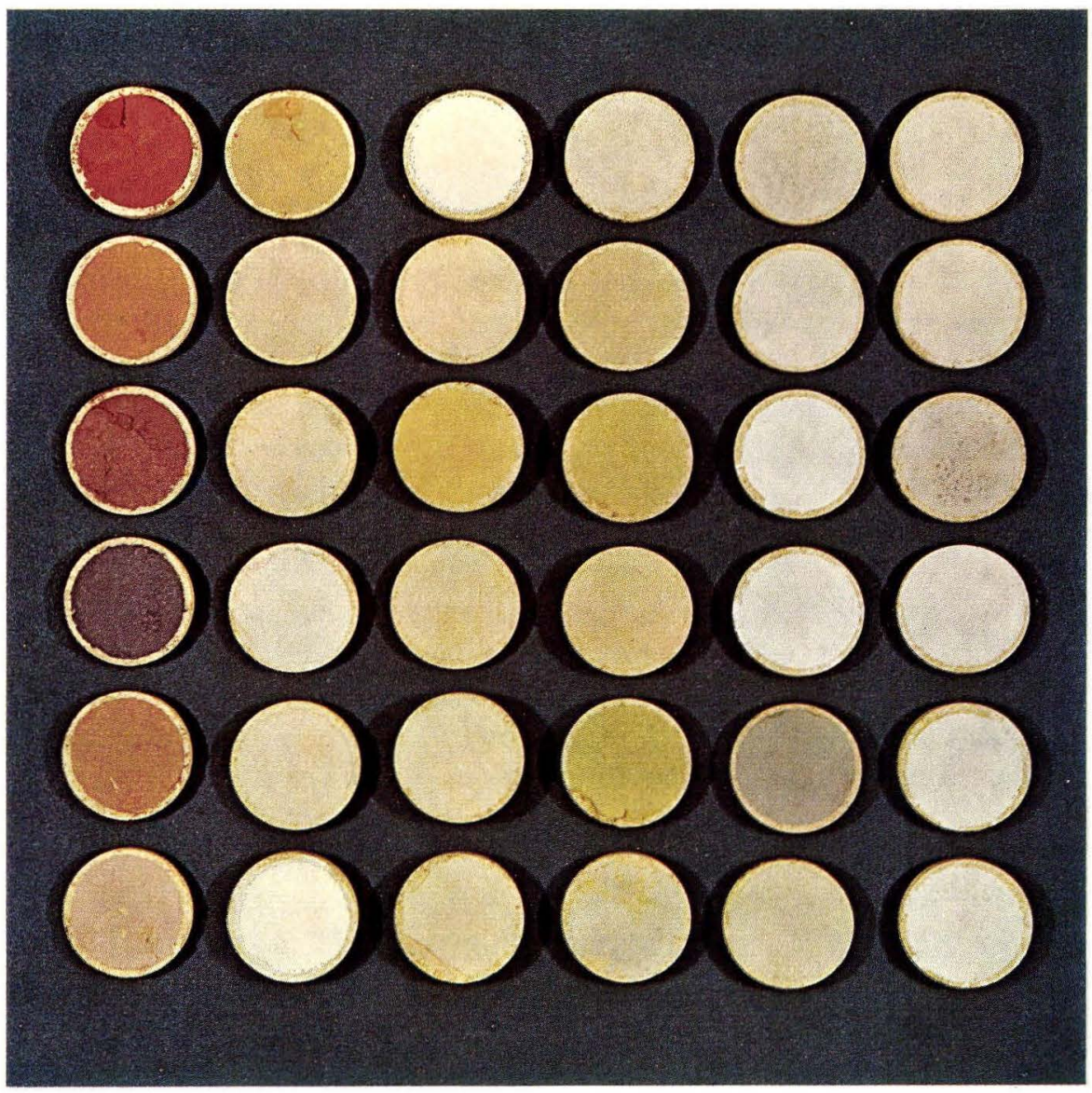

Photo No. 8. Colourstandard for ignited samples. (Explanation, see text). 
chemical composition of the colour standards (photo No. 8) should be calculated satisfactory.

Detailed knowledge of the reactions during ignition, and especially the end-products of the individual elements, is prerequisite for the explanation of the connexion between the chemical composition and the colour-conditions. The ignition was carried out at a temperature of $860^{\circ} \mathrm{C}$ over a period of at least 5 hours. Because of the long time of ignition, reactions which normally take place at a temperature somewhat higher than $860^{\circ} \mathrm{C}$ cannot always be excluded.

As a control on this, a series of X-ray diffractometer investigations were carried out on the ignited samples of the colour standard. The results of these investigations, combined with informations from HëGG (1964) under the conditions used, show that the following endproducts and reactions are possible:

Dark-red/violet: $\quad \mathrm{Fe}_{2} \mathrm{O}_{3}$.

Dark violet: $\quad \mathrm{Fe}_{3} \mathrm{O}_{4}\left(\mathrm{Fe}_{2} \mathrm{O}_{3} \rightarrow \mathrm{Fe}_{3} \mathrm{O}_{4}\right.$ at temp. above $\left.700^{\circ} \mathrm{C}\right)$.

Bright red: $\quad(\mathrm{Fe}, \mathrm{Al})_{2} \mathrm{O}_{3}$, which is stable until $1100^{\circ} \mathrm{C}$.

Yellow:

Ferruginous clay, with a low content of $\mathrm{SiO}_{2}$ and a high $\mathrm{CaO}$-content, will by firing be yellow (cf. bricks).

White: $\quad$ Firing of $\left(\mathrm{Al}_{2} \mathrm{O}_{3} \cdot 2 \mathrm{SiO}_{2} \cdot 2 \mathrm{H}_{2} \mathrm{O}\right)=$ iron-free kaolin.

White: $\quad$ Firing of $\mathrm{CaCO}_{3} \rightarrow \mathrm{CaO}+\mathrm{CO}_{2}$.

White: $\quad \mathrm{CaSO}_{4} \cdot \mathrm{H}_{2} \mathrm{O} \rightarrow \mathrm{CaSO}_{4}$. If the process takes place at temperatures above $200^{\circ} \mathrm{C}$ gypsum dehydrates and is not able to take up water again.

White: $\quad \mathrm{TiO}_{2}$ : $\mathrm{Ti}^{4+}$ can fill $\mathrm{Al}^{3+}$ and $\mathrm{Fe}^{3+}$ lattice sites in clay. Black/brown-black: $\quad \mathrm{Mn}_{2} \mathrm{O}_{3}$, is formed by Mn-compounds by heating at temperatures below $900^{\circ} \mathrm{C}$.

The colour-standards (see photo No. 8) can, with the exception of the green colours, be regarded as different degrees of mixture of red, white/ yellow, and brownish-black. Mixtures between the strong colours red and brownish-black will give dark shades, and variations in their degree of mixing are difficult to clarify. Red and white/yellow will together give lighter red shades. By addition of brown-black the light colour will darken and eventually become dark-grey or chocolate-brown. Mixtures between black and white/yellow will have a corresponding influence without red shades.

If the three colouring-substances: $\mathrm{Mn}$ (brown-black), $\mathrm{Fe}$ (red) and $\mathrm{Ca}+$ $\mathrm{Si}+\mathrm{K}+\mathrm{Al}+\mathrm{Ti}=$ "clay" (yellow/white) are shown on a triangular-diagram it will theoretically appear as in fig. 18. In fact only very small amounts of $\mathrm{Mn}$ are needed to alter the colour to grey and brown-black (about $0.5 \%$ ). $10 \% \mathrm{Fe}$ gives in general red colours, but a Fe-content 


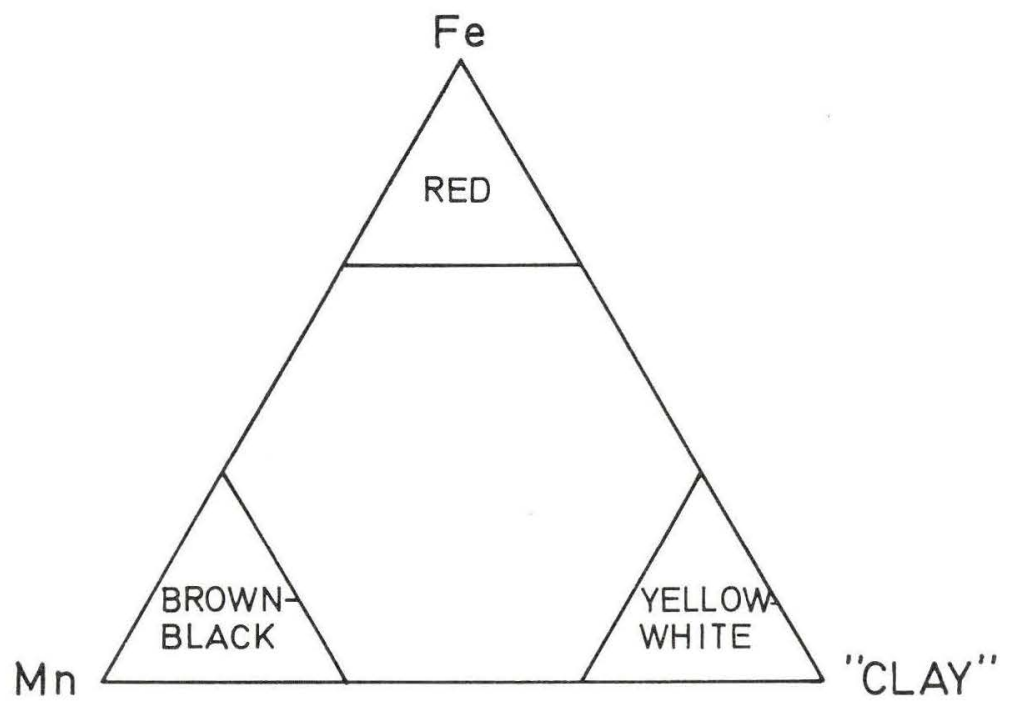

Fig. 18. Theoretical correlation between colour and chemistry for ignited samples.

of $1 \%$ is sufficient to show a red tint. The white or yellow colour only appears with very high "clay"-contents.

The green colours, which do not fit into this system, were excluded from further treatment. The green colour may be caused by some elements that have not been analysed.

Fig. 19 shows the distribution of the peat-, gyttja-, and clay-samples in a triangular diagram. In the case of the peat there is accordance between chemistry and colour. The gyttja- and clay-samples fit into the system, but the sand-samples do not. The colour of the sand-samples given by small contents of $\mathrm{Mn}$ and $\mathrm{Fe}$ is just as strong as the colour of the gyttja- and claysamples with much larger $\mathrm{Mn}$ - and Fe-contents. This may be because $\mathrm{Si}$ is a less effective diluter of red and brown colours than $\mathrm{Ca}$ which dominates in the gyttja. The sand-samples were excluded from further work.

As it appeared that the same colour shade corresponded to the same distribution of Fe, Mn and "clay", independent of whether the sample was gyttja, clay or peat, one diagram (e. g. fig. 19) is sufficient to convert the colour of an arbitrary sample into $\mathrm{Fe} / \mathrm{Mn} /$ "clay"-ratios. The calibration of the diagram must consider both the lithological and chemical differences. The content of especially $\mathrm{Fe}$ and $\mathrm{Mn}$ can therefore be given for gyttja, peat and clay samples from the colour of the ignited sample. As loss on 


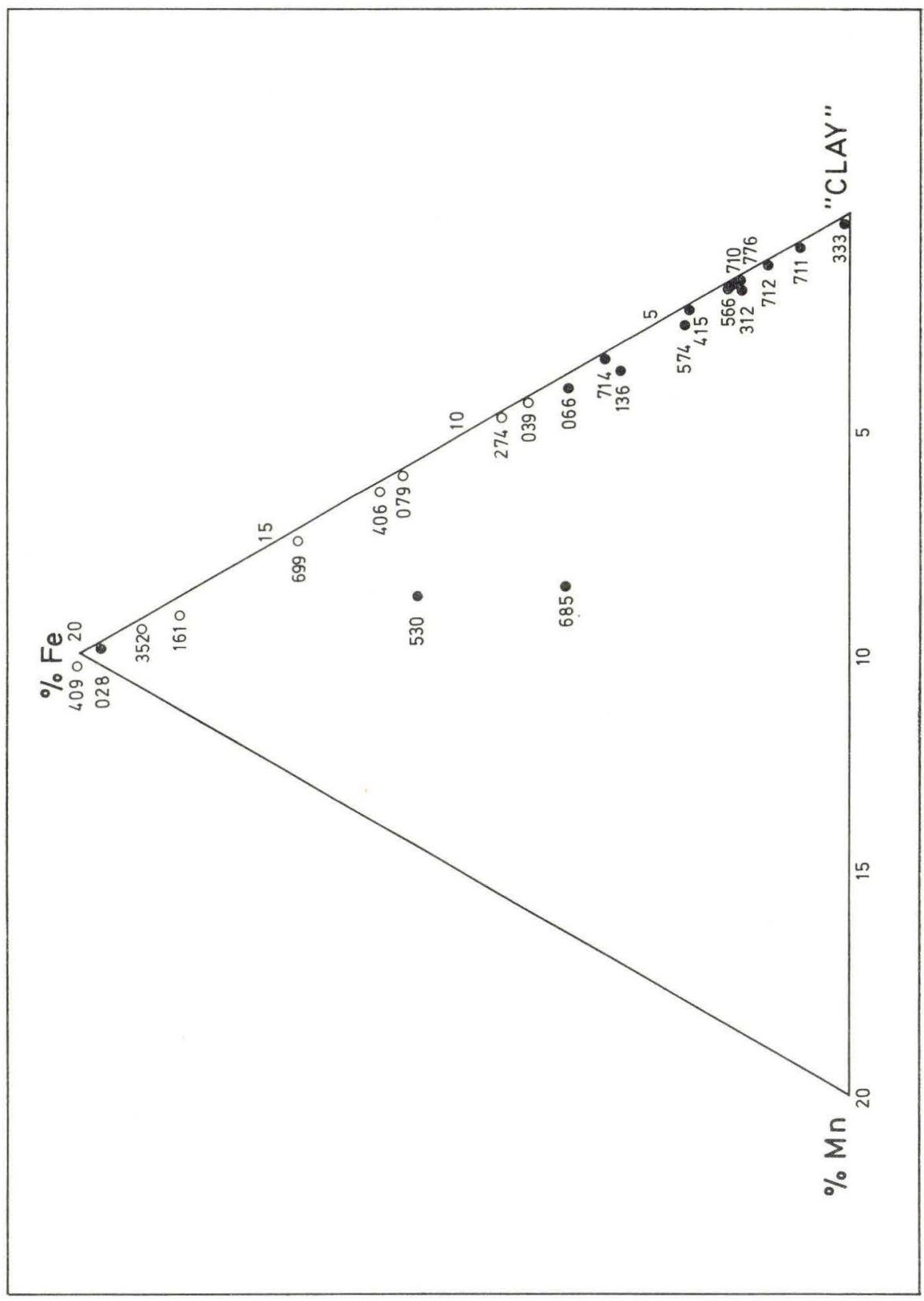

Fig. 19. Conversion diagram. Correlation between colour and chemistry for samples in the colour-standard (photo No. 8). Open circles = peat; filled circles = gyttja and clay. 
ignition will normally be carried out during investigations of this sort, information about the Fe- and Mn-distribution is relatively easily obtained. The possibility of measuring the colour of the ignited samples more objectively has been tested (by means of monochromatic light, rock colour chart etc.) but no satisfactory method has yet been found.

\section{Distribution of iron and manganese in the Rosenholm depression:}

The mapping of the distribution of Fe/Mn/"clay" in the Rosenholm depression is carried out by a subjective comparison of the ignited sample to the colour-standard (photo No. 8), and by means of the "conversion-diagram" (fig. 19), which is valid for peat-, gyttja- and clay-samples which have been ignited at $860^{\circ} \mathrm{C}$. The content of iron and manganese is presumably supplied in solution to the depression from the surrounding area, either by groundwater flow at a certain depth or by small nearsurface streams.

Iron-distribution: The Fe-content of the peat is normally about 15-20\%. $(\mathrm{Fe}+\mathrm{Mn}+$ "clay" $=100 \%)$. The gyttja has 3-6\% Fe and the clay about $10 \%$.

The iron-content seems to distribute thus:

1. A constant, high Fe-content through the whole series of layers.

2. Very large Fe-concentrations in the nearshore sandlayers.

3. A high Fe-content at the transition between peat and gyttja.

Examples and possible explanations of the formations of these deposits are given below.

At boring 64 (location see fig. 3) there is an outlet of a small stream which presumably over a long period of time (syngenetic) supplied considerable amounts of $\mathrm{Fe}$ to both the gyttja-lake and the peat-bog, as in the neighbouring deep boring (No. 66) an anomalously high Fe-content was found through most of the series of layers (fig. 20). The same phenomenon is to be seen in the boring Hornslet Mose 79.

The high near-shore Fe-concentrations are normally found in the sandlayers which underlie the peat (borings Nos. 39, 42 (fig. 20), 46, 47, $48,52,59,64$, a. o.). The Fe-content in the sand seems to decrease rapidly downwards. These Fe-deposits may have been deposited after the peat was formed, either by an influx to the sand-layer proper (i. e. by the groundwater at a shallow depth), or to the upper parts of the peat through which the Fe migrated downwards and concentrated in the sand-layer. Alternatively they may represent earlier supplies of Fe to the basin before the peat started to cover the area. If the iron is deposited in an oxygenated form, e. g. as ochre, this last possibility seems to be the most reasonable, as the Eh under a peat-cover of more than a metre is found to be so low that the 

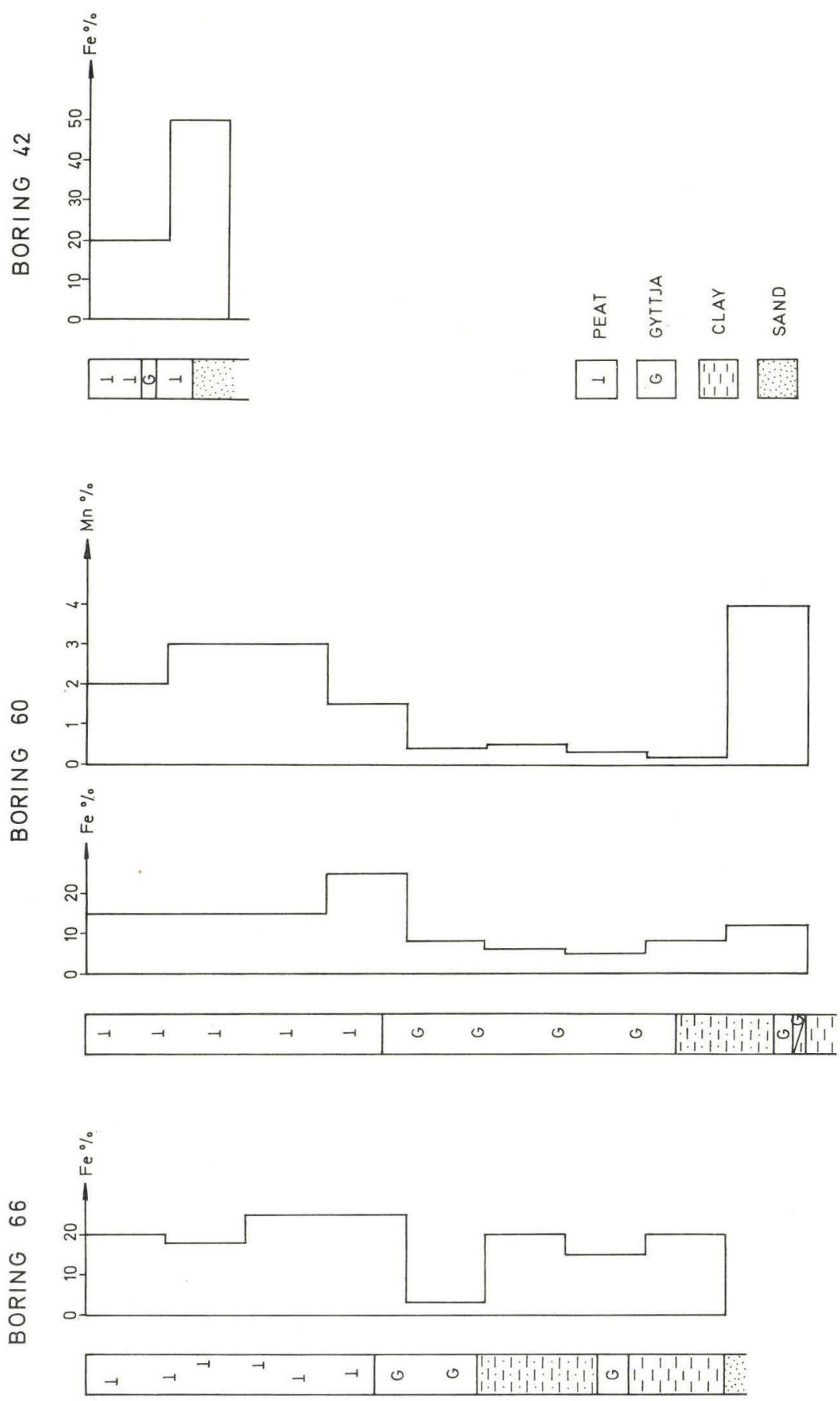

Fig. 20. Examples of Fe- and Mn-distribution in the Rosenholm depression. 
transition $\mathrm{Fe}^{++} \rightarrow \mathrm{Fe}^{+++}$is inhibited. The mineral paragenesis of the ferruginous sand-layer is not further investigated. The Fe which colours the ignited samples may originally have been sedimented as the reduced form. The possibility that the Fe was deposited as a sulphide seems likely since $\mathrm{FeS}_{2}$ has been detected in several cases.

The high concentrations of iron which are occasionally found in the upper part of the gyttja (borings Nos. 37, 45, 60 (fig. 20), and 66) are conceivably formed by a downward seeping of ferruginous water through the peatlayer. When the water met with the lime-rich gyttja environment, reactions which have bound the iron in some form or another must have taken place (e. g. combined as carbonates). Which reactions occurred cannot be determined since the mineralogical composition has not been investigated in sufficient detail.

Mn-distribution: The peat has in general a very modest content of $\mathrm{Mn}$ (0.1.-0.2 \%), but in a few cases considerable amounts have been found (up to about $3 \%$ ) especially in its upper parts (e. g. borings Nos. 21, 24, 33, 56, 58, 60 (fig. 20)).

Manganese is especially abundant in the gyttja, particularly in the Allerød-gyttja. In general the Mn-content increases with depth in the gyttjaprofile. It is generally accepted (KRUMBEIN and GARRELS 1952) that Fe and $\mathrm{Mn}$ complexes are influenced similarly by changes in $\mathrm{Eh}$ and $\mathrm{pH}$, and that the $\mathrm{Mn}$ goes into solution more readily than the Fe.

Measurements of $\mathrm{pH}$ and $\mathrm{Eh}$ in the depression showed that $\mathrm{pH}$ today is lower and Eh higher than at the time of formation. The Mn-complexes therefore may have been unstable after the deposition and there is the possibility that some of the original Mn-content was washed out before the $\mathrm{Fe}$ was essentially mobilized. As support for this suggestion it is noted that the Eh is low in the gyttja, and the lowest values have been measurered in the Allerød-gyttja, where the content of $\mathrm{Mn}$ is the greatest. There is no reasonable explanation yet for the high $\mathrm{Mn}$-concentrations in the upper part of the peat. 


\section{EH AND PH OF THE ENVIRONMENT OF FORMATION}

The varied lithologies in the sequence represent different environments. By investigation of the mineral assemblages of the individual layers the $\mathrm{pH}$ and Eh of the environments of formation can be indicated (KRUMBEIN and GARRELS 1952). The mineralogical composition of parts of the sequence has been determined by X-ray diffraction and chemical methods. The following parameters have been used as environment-indicators: $\mathrm{CaCO}_{3}, \mathrm{FeS}_{2}$ (which in the ignited sample occur as $\mathrm{CaSO}_{4}+\mathrm{Fe}_{2} \mathrm{O}_{3}$ ) the organic content (determined as reduced loss on ignition), the colour of the fresh sample, and $\mathrm{H}_{2} \mathrm{~S}$-smell.

The peat. The high organic content and an occasionally large amount of $\mathrm{FeS}_{2}$ show (KRUMBEIN and GarReLs 1952) that Eh has been negative. $\mathrm{pH}$ must have been low in the peat, because of its content of acid humic matter (HANSEN 1959, 1966).

The gyttja's high lime-content shows that the environment was alkaline $(\mathrm{pH}>7.8)$. The content of organic matter in the gyttja is in places considerable, and it may be recognized that the oxygen-level of the lake-bottom has been low. At a shallow depth the biogenic reactions have presumably lowered the Eh to negative values.

The clay-layers. Due to the lime-content and its low organic content, the clay is assumed to have been deposited under approximately the same Eh$\mathrm{pH}$ conditions as the gyttja.

The Allerød-gyttja. The colour, the $\mathrm{FeS}_{2}$-content and the organic content show that the environment was anaerobic. The lime-content indicates high $\mathrm{pH}$ conditions. Therefore the peat, with a low $\mathrm{pH}$, laid above the gyttja and clay-layers with high $\mathrm{pH}$ values and reactions occurred at the contact. Circulating movements in the groundwater and water seeping downwards through the layers of peat have presumably mixed the pore-fluids of the two environments, with the result that considerable parts of the gyttja have been subjected to solution. 


\section{SOLUTION-PHENOMENA}

The fossils show several signs of corrosion, but the gyttja itself is so finegrained and amorphous that solution-phenomena cannot be seen. In an investigation carried out in the bog of Barmosen, MARCUSSEN (1967) states that opercula from the snail Bithynia tentaculata are sometimes abundant, and he takes their frequency too prove that the rest of the snail was removed by water currents which were unable to remove the flat opercula.

Bithynia tentaculata also occurs in the Rosenholm depression but in the cases where only the opercula remains there is little doubt that the rest of the snail has been removed by solution. As an example of this two samples from the gyttja-layer in boring No. 21 are presented:

In the lowermost sample a mixture of opercula and partly dissolved bivalves and snails occurs. The opercula are grey or blue-grey and show no signs of corrosion. About $1 \frac{1 / 2}{\mathrm{~m}}$ higher in the profile only white opercula with corroded surfaces are found. After the corrosion has started the opercula are very fragile and are easily damaged. The reason why the opercula resists solution is probably that they, in contrast to the shell proper, contain chitin, which inhibits the entrance of the acidic porefluid to the calcareous material.

The development of the white colour in the opercula is the first sign that solution has started. In several cases, particularly in the gyttja-layers just below the peat, only white spots remain as the last visible signs of the fauna. 


\section{RECENT EH AND PH-CONDITIONS}

Measurements of $\mathrm{pH}$ and $\mathrm{Eh}$ showed that the recent environment is more acid, and has a higher Eh than the environment of formation. Fig. 21 shows in a stability diagram (after KRUMBEIN and GARRELS 1952) the recent pHEh conditions of the peat. In all cases the Eh-values lie outside the field of stability for organic material. The recent environment of the gyttja is shown in fig. 22. No pH-measurements are found in the lime stability-field. The sediments of the Rosenholm depression are therefore undergoing solution. The rate of decomposition is not known, but it can be supposed that drainage in the last 50 years has accelerated the speed of the corrosion since the water renewal has been more effective.

Eh-variations: The highest Eh-values are found in the top metre of the peat, where the water-content is uniform (see the profil diagram from boring Bendstrup 60, fig. 10). In many borings the Eh values are about + $450 \mathrm{mV}$-no doubt because of atmospheric influence. The groundwatertable is reached at a depth of about $1 \mathrm{~m}$, and is registered in the Eh-graph by a discontinuity where the values drop from $+450 \mathrm{mV}$ to almost +200 $\mathrm{mV}$ through a zone of not more than $20 \mathrm{~cm}$ in thickness. Throughout the peat the Eh is constant at about $+200 \mathrm{mV}$. In the rest of the profile Eh lies at about $+150 \mathrm{mV}$, only interrupted by the slightly lower values (about $+60 \mathrm{mV}$ ) of the Allerød-gyttja. In the sand substratum the Eh rises again. Mortimer (1942) states that when $\mathrm{E}_{7}$ is less than $+200 \mathrm{mV}\left(\mathrm{E}_{7}=\mathrm{Eh}\right.$ at $\mathrm{pH}=7)$ the oxygen content is zero. With the exception of the top metre of the peat, there is consequently no oxygen present in the sediments of the Rosenholm depression.

pH-variations: Below the groundwater-table $\mathrm{pH}$ increases gradually from about 6 in the peat to about 7 in the gyttja. The pH of the Allerød-gyttja is generally higher than that of the Postglacial gyttja. $\mathrm{pH}$ increases to about 8 in the Lateglacial bottom sand.

The recent $\mathrm{pH}$ and Eh-conditions constitute a measure of respectively acidity and redoxequilibrium in a fluid which is formed by mixing the porefluids of the peat-, gyttja- and clay-deposits. The mixing takes place due to movements of the ground water. The measurements seem to indicate the existence of 3 partly separated flows:

1. In the upper part of the sequence the $\mathrm{pH}$-values increase gradually downwards from the peat to the gyttja. The water seeping down is neutralized by the gyttja. The mixed pore-fluid is not at first in equili- 


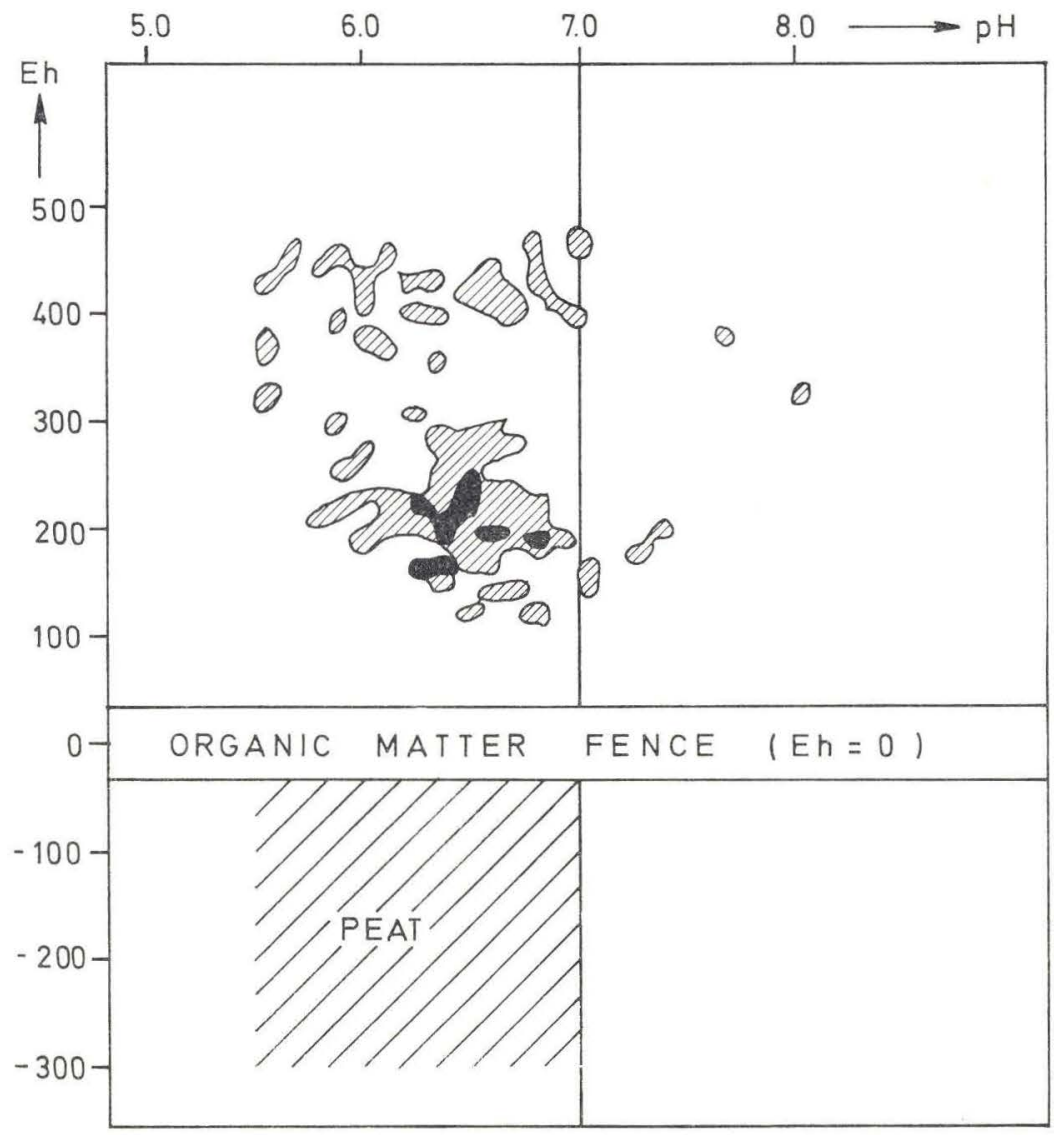

NUMBER OF MEASUREMENTS

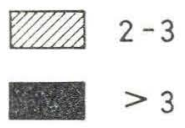

Fig. 21. Peat's recent pH/Eh-conditions. (Modified after Krumbern and Garrels 1952).

brium with the lime-gyttja (see the comparison between field and laboratory measurements of Eh and $\mathrm{pH}$, fig. 2), but after a few hours the porefluid is totally neutralized. This must indicate that a constant supply of acid waters from above takes place.

2. The Allerød-gyttja is separated from the upper-part of the sequence by a layer of clay. Its higher $\mathrm{pH}$ and lower Eh (fig. 10) may be caused by one of two mechanisms. The supply of acid water from above may take place so slowly that the lime in the gyttja neutralizes the pore-fluid and the biogenic reactions which take place in the Allerød-gyttja give rise 


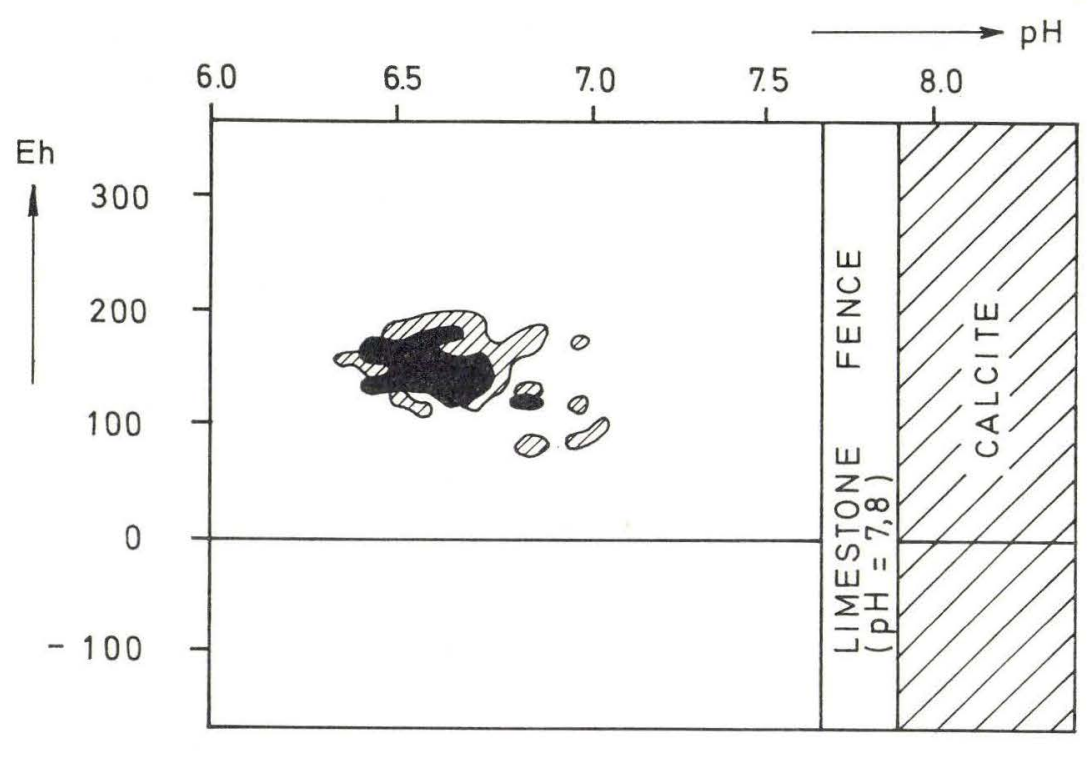

NUMBER OF MEASUREMENTS

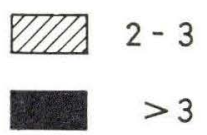

Fig. 22. Gyttja's recent pH/Eh-conditions. (Modified after KrumbeIN and Garrels, 1952).

to a low Eh. Alternatively the Allerød-gyttja may recieve a neutral, oxygen-poor solution by horizontal movements of ground-water within the Allerød-gyttja. The content of $\mathrm{Mn}$, which gradually increases downwards in the profile (fig. 20), may indicate that the water-supply to the Allerød-gyttja has some connection with the layers above. It therefore seems reasonable to accept that the upper clay is able to restrain the water-seeping from above so much that the acidity can be neutralized and the oxygen-content used up.

Thus ground-water movements in the Allerød-layer are akin to the movements in the upper parts of the profile, but as the neutralizing and the oxygen consuming processes have a longer time at their disposal, the pore-fluid reaches a higher $\mathrm{pH}$ and a lower Eh than in the remaining strata.

3. In the Lateglacial sand deposits both $\mathrm{pH}$ and $\mathrm{Eh}$ increase in general. This indicates that the pore-fluid of the sand is not supplied with any significant amounts of water from above, which is certified by the distribution of the iron (fig. 20). It is therefore assumed that the sand 
has its own groundwater flow which supplies alkaline water to the lowermost layers of the bog, the oxygen-content of which is relatively large. As the Rosenholm depression forms part of a larger area of drainage it may be assumed that the fairly high $\mathrm{pH}$ - and Eh-values are a result of the passage of large amounts of water from the surrounding area through the Lateglacial sand-deposits below the Rosenholm depression. 


\section{LATE- AND POSTGLACIAL WATER-COVERING IN THE DEPRESSION}

Lateglacial sediments only cover a limited part of the Rosenholm depression (e. g. the lower clay is found in only a few borings), but subsequently more and more of the basin has been involved in sedimentation-processes. As the chief part of the sediment is deposited below a certain depth of water a general increase of water depth seems to have occured in the area in Late- and Postglacial time.

The question as to the absolute depth of water in connection with the deposition of the individual layers has been mentioned above and it was stated that local conditions in the basin (e. g. sheltering in the gyttja-lake) play such a significant role that a depth of water calculated at one place, cannot with any certainty be expected to hold for the depression as a whole.

At the outlet of the Rosenholm river near Andi, a sand-barrier is found at about $2 \mathrm{~m}$ depth (boring No. 71). This probably dammed the lake, until the peat overgrew it and acted as an upper limit for the water depth. Therefore the sedimentation must have taken place below a maximum watercover which was ca. $2 \mathrm{~m}$ less than the depth of boring, ignoring any later compaction. 


\section{POSTGLACIAL CHANGES IN WATER-LEVEL}

Mertz (1924) outlined the variations of the Littorina transgressions all over Denmark and mentioned that in the Rosenholm area the Littorina sea reached 3-4 m above present sea level. IVERSEN (1937) showed by investigations of Søborg lake that more Littorina transgressions had occurred (3 Atlantic and 1 Subboreal). The Littorina sea reached Klintes $\varnothing$ in Odsherred twice (JESSEN 1937) and in Korup lake, situated about $15 \mathrm{~km}$ from Rosenholm depression, 3 marine events were registered (IVERSEN 1937).

Korup lake was separated from Kolindsund by a barrier about $3 \mathrm{~m}$ above present sea level. The Rosenholm depression lies slightly higher, and there is no evidence of marine transgression found in its strata.

Floating bogs are taken as an indication of increasing water level by Troels-Smith $(1951,1953)$, but there is the possibility that the floating bogs have been torn off in stormy conditions and have continued their growth while floating. The floating bogs in the Rosenholm depression (in borings Nos. 36, 42 and 51, see fig. 15) are all found nearshore, and may have been formed by increasing water levels. In borings 36 and 51 three floating bogs have been found; in boring 42, where the profile is less, only one has been detected. The floating bogs are assumed to have formed during the increases of water level in the depression caused by the Littorina transgressions.

Troels-Smith (1956) has put forward the idea that the Littorina transgressions correspond to desiccations in the bogs, or a minimum water level in the lakes (JøRGENSEN 1963), since the expansion of the Littorina-sea is due to increased icemelting which is favoured by a warmer climate. In a warmer period, evaporation increases, and thus the water level in the lakes decreases. On the other hand the water level in a lake will increase in a cooler period, where the sea withdraws. Investigations in the bog of Aamosen (JørGENSEN 1963) support this assumption, since increases of water-level are displaced relative to the Littorina transgressions.

Variations of water level in a lake-basin may be thought to represent more than variations in precipitation and evaporation of the draining area. The water level of the larger lakes is governed by the height of the groundwater-table, which is partly influenced by the conditions of precipitation and partly by the level of the oceans. It is therefore to be expected that the higher water level of the Littorina-sea will raise the groundwater-table, and thus increase the water level in the lake basins. The rising water level in 
the lakes follows the transgression after a short delay so that TroelsSMITH may be correct in saying that the Littorina transgressions are not registered simultaneously in the lake basins by an increased water level.

Thus it seems reasonable to connect the floating bogs in the depression with the changes in the Littorina-sea, but as long as the questions concerning age remain unsolved, this assumption must be taken with reservation. 


\section{CONCLUSION}

The development of the Rosenholm depression during Late- and Postglacial times can be summarized as follows:

The depression, which is assumed to have existed before the meltingperiod, was modified by Lateglacial melt-water from the ice, which formed Kalø Creek and parts of the East Jutland border-moraine. The filling of the basin started with creeping soil and outwash materials.

The Allerød oscillation was registered by a locally anaerobic gyttjasedimentation in the NW-part, while Allerød-soil and -peat was deposited in the SE-part and in the bog of Hornslet. The two parts of the depression were separated by a Lateglacial sand barrier. The Rosenholm depression was subsequently divided into two parts until the peat covered the barrier. In the NW-part outwash materials were sedimented above the Allerød-gyttja until, probably at the transition Late/Postglacial a gyttja-formation began. In the SE-part of the depression and in the bog of Hornslet dy was deposited directly on the Allerød-layer. The overgrowth of peat started from the edges of the basin, supposedly in the Atlantic time or late in the Boreal time. It is not known when the growth of the peat-cover terminated.

The depression was drained several times and is at present used as a grazing-area.

The whole series of layers is undergoing decomposition, and it can be assumed that the Late- and Postglacial sediment-cover of the depression will eventually disappear. 


\section{ACKNOWLEDGEMENTS}

The author wishes to express his thanks to professor dr. phil. GUNNAR LARSEN, Aarhus, under whose supervision the work was carried out. Thanks are also given to Mrs Lissie JANS who prepared the drawings, and to Dr. J. R. WILSON who corrected the English manuscript which was completed in March 1972. 


\section{DANSK SAMMENDRAG}

Rosenholm lavningen er en langstrakt tørvefyldt depression i det ungglaciale landskab foran Harders randmoræne. Den er navngivet efter Rosenholm Slot, der ligger mellem Hornslet og Mørke på den E-lige del af kortbladet Randers (fig. 1).

Undersøgelsen, der omfattede to adskilte tørvedækkede bassiner (Hornslet Mose og Rosenholm lavningen, fig. 1), indledtes med en dybdekartering (fig. 3) med mosebor (system Hiller). I felten blev pH og Eh målt med et transportabelt $\mathrm{pH}$-meter. På prøvematerialet bestemtes i laboratoriet vandindhold, glødetab, kalkindhold, opalindhold, humuficeringstal, indhold af organisk bundet $\mathrm{C}$ og $\mathrm{N}$, gløderesternes indhold af $\mathrm{Ca}, \mathrm{Al}, \mathrm{Ti}, \mathrm{K}, \mathrm{Si}, \mathrm{Fe}$ og $\mathrm{Mn}$; der foretoges en kemisk analyse af nogle prøver før og efter glødningen, mineralindholdet blev bestemt, og der optoges radiografier af en intakt borekerne.

Lagseriens opbygning (se fig. 5):

I ét tilfælde nåedes kontakt med moræenen, der overlejres af stærkt vandførende smeltevandssand. Over dette følger en $1 \frac{1}{2} \mathrm{~m}$ mægtig lagdelt moræneagtig aflejring (foto $\mathrm{nr} .1$ ), der tolkes som flydejord.

Boringerne afsluttedes normalt et lille stykke nede i det senglaciale sand, der overlejrer flydejorden, idet det ikke er muligt at trænge gennem selv beskedne sandlag med moseboret. Sandaflejringens topografi (fig. 6) synes at støtte en formodning om lavningens subglaciale fortid (tunneldal). Over det senglaciale bundlag følger den nedre ler, en ca. $3 \mathrm{~m}$ mægtig serie af vekslende sand-, silt- og lerlag, hvoraf en del ses på foto 4 og 5. Fig. 7 viser udbredelse, lithologi og dybde for Allerød-laget, der faciesmæssigt er 3-delt i Rosenholm lavningen: I den NW-lige del findes en stedvis euxinisk gytje afsat på ganske lavt vand; i den SE-lige del Allerød-muld og -tørv og i Hornslet Mose sphagnum tørv. Lavningen er to-delt af en senglacial sandtærskel ved jernbaneoverføringen. På foto 6 ses Allerødgytjen, der er blåsort med gule gravegange. Lagets lejringsforhold er vist på fig. 8. Mellem boring $\mathrm{G}$ og Bendstrup 60 synes laget at være forkastet, hvilket sættes i forbindelse med bortsmeltning af dødis fra underlaget. Aller $\varnothing$ dlaget overlejres af den фvre ler, der ses på foto 7. Den nedre og den $\varnothing v r e$ ler anses for at være dannet af lokalt nedskylsmateriale.

Antagelig på overgangen til postglacialtiden startede gytjeafsætning i lavningen. Gytjens maksimale udbredelse fremgår af fig. 9. Det ser ud til, at 
gytjen, der er op mod $4 \mathrm{~m}$ mægtig, og som bl. a. indeholder meget kalk, blev afsat i en eutrof $s \varnothing$. C/N-forholdet afslører (fig. 12), at NW-enden var en gytje-s $\varnothing(\mathrm{C} / \mathrm{N}=10)$, mens SE-endens sedimenter er dy og tyrfopel. Gytjen efterfølges af tørv. Fig. 15 viser et eksempel på, at sphagnumagtige hængesække har bredt sig et stykke ud i gytje-søen. Hængesækkene kan formentlig sættes i forbindelse med littorinatransgressionerne. På tørven, der stedvis er op mod $4 \mathrm{~m}$ mægtig (fig. 16) er gennemført en humuficeringsanalyse (fig. 17). De klimasvingninger, der er påvist i højmosetørv i nærheden af lavningen (BAHNSON 1968), kan ikke genfindes her.

Gløderesternes farve. De glødende prøver varierede meget i farve (foto 8). Det skønnedes, at $\mathrm{Ca}, \mathrm{Al}, \mathrm{Ti}, \mathrm{K}, \mathrm{Si}, \mathrm{Fe}$ og $\mathrm{Mn}$ især kunne have indflydelse herpå, idet $\mathrm{Ca}, \mathrm{Al}, \mathrm{Ti}, \mathrm{K}$ og $\mathrm{Si}$ (= "ler") tilsammen kan give gule og hvide farver ved brænding, mens $\mathrm{Fe}$ og $\mathrm{Mn}$ bidrager med henholdsvis rødt og brunsort. Blandinger af disse (fig. 18) kan stort set forklare farvestandardens nuancer (foto 8). Ved at sammenligne en vilkårlig gløderests farve med foto 8 og fig. 19 kan Fe, Mn, "ler" \% angives, og fordelingen i hele lavningen kortlægges. Fig. 20 viser eksempler på fordelingen.

pH og Eh i lavningen. Dannelsesmiljøets pH og Eh kan i store træk klarlægges ved at unders $\varnothing$ ge de enkelte lags mineralparagenese (KRUMBEIN og GARRELs 1952). Tørvens store indhold af organisk stof og sure humusstoffer tyder på, at Eh var negativ og $\mathrm{pH}$ lav på dannelsestidspunktet. Gytjens kalkindhold tyder på alkaline forhold (med $\mathrm{pH}>7,8)$. Indholdet af organisk stof er stedvis betydeligt, så man må også her regne med lave Eh-værdier. Det samme er tilfældet i Allerød-gytjen, hvor $\mathrm{FeS}_{2}$ er påvist. Tørvens sure miljø ligger altså som et kalkaggressivt dække over gytje- og lerlagene, og man må vente at en sammenblanding af porevæskerne vil finde sted med kalkopløsning til følge. At dette har været tilfældet ses i gytjen af fossilindholdet, som viser tydelige tegn på ætsning. I den øverste del af gytjen er skaller af Bithynia tentaculata næsten fjernet, mens de kitinholdige opercula endnu er tilbage. Målinger af Eh viste, at det recente miljø er mere surt og har et højere redoxpotentiale end dannelsesmiljøet. (Fig. 21 og 22). Da både pH og Eh-værdierne ligger væsentligt uden for stabilitetsfeltet, må man formode, at hele lagserien i Rosenholm lavningen er under nedbrydning. 


\section{REFERENCES}

ANDERSEN, S. T. 1966: Interglacial vegetational succession and lake development in Denmark. Palaeobotanist 15, 1-2, pp. 117-127.

- 1969: Interglacial vegetation and soil development. Bull. geol. Soc. Denmark,19, pp. 90-102.

BaHnson, H. 1968: Kolorimetriske bestemmelser af humuficeringstal i højmosetørv fra Fuglsø Mose på Djursland. Meddr. Dansk Geol. Foren. 18, pp. 56-64.

Christensen, W. 1962: Betragtninger over den geokemiske udvikling i de øvre jordlag i Danmark. Meddr. Dansk Geol. Foren. 15, pp. 112-122.

DaU, I. H. C. 1823: Neues Handbuch über den Torf etc. Leipzig.

- 1829: Bericht über die Torfmoore Seelands nach einer im Herbst 1828 deshalb unternommenen Reise. Kopenhagen und Leipzig.

Godwin, H. 1954: Recurrence - surfaces. Danmarks Geol. Unders. 2. række, 80, pp. 22-30.

GRY, H. 1935: Petrology of the Paleocene Sedimentary Rocks of Denmark. Danmarks Geol. Unders. 2. række, 61.

Hansen, K. 1956: The Profundal Bottom Deposits of Gribsø, pp. 16-24. In: K. Berg \& I. C. Petersen: Studies on the Humic, Acid Lake Gribsø. Folia Limnol. Scand. nr. 8.

- 1959: The Terms Gyttja and Dy. Hydrobiologica 13, pp. 309-315.

- 1961: Lake Types and lake sediments. Verh. Internat. Verein. Limnol. 14, pp. 285-290.

HANSEN, K. 1962: The dystrophic lake type. Hydrobiologica 19, pp. 183-191.

- 1964: Oversigt over danske Søsedimenter. Meddr. Dansk Geol. Foren. 15, pp. 426-430.

- 1964: The Post-Glacial development of Grane Langsø. Meddr. Dansk Geol. Foren. 15, pp. 446-458.

- 1966: Nordens ferske vande. Københavns Universitets Geografiske Institut, 1966.

- 1968: En boring i Esrom Sø. Meddr. Dansk Geol. Foren., 18, pp. 244-246.

Hansen, S. 1940: Varvighed i danske og skånske senglaciale Aflejringer. Med særlig Hensyntagen til Egernsund Issøsystemet. Danmarks Geol. Unders. 2. række, 63.

- 1965: The Quaternary of Denmark. - In Kalervo Rankama (Editor). The Quaternary, 1, Interscience Publishers, p. 67.

Harder, P. 1908: En østjydsk Israndslinie og dens Indflydelse på Vandløbene. Danmarks Geol. Unders. 2. række, 19.

Hartz, N. 1912: Allerød-Muld; Allerød-Gytjens Landfacies. Meddr. Dansk Geol. Foren. 4, pp. 61-68.

Hartz, N. og Milthers, V. 1901: Det senglaciale Ler i Allerød Teglværksgrav. Meddr. Dansk Geol. Foren. 2, nr. 8, pp. 31-60.

HäGG, G. 1964: Allmän och oorganisk kemi. Almqvist \& Wiksell, Stockholm.

IVERSEN, J. 1937: Undersøgelser over Litorinatransgressioner i Danmark (Foreløbig Meddelelse). Meddr. Dansk Geol. Foren. 9, nr. 2.

- 1941: Landnam i Danmarks Stenalder. En pollenanalytisk Undersøgelse over det første Landbrugs Indvirkning på Vegetationsudviklingen. Danmarks Geol. Unders. 2. række, 66.

- 1954: The Late-Glacial Flora of Denmark and its Relation to Climate and Soil. Danmarks Geol. Unders. 2. række, 80, pp. 87-119.

JESSEN, K. 1937: Litorinasænkningen ved Klintesø i pollenfloristisk Belysning. Meddr. Dansk Geol. Foren. 9, nr. 2. 
JøRGensen, Sv. 1963: Early Postglacial in Aamosen. Geological and Pollen-analytical Investigations of Maglemosian Settlements in the West-Zealand Bog Aamosen. Danmarks Geol. Unders. 2. række, 87.

JÄrNEFELT, H. 1952: Limnological classification of Lakes. In: SuomI, a general handbook on the geography of Finland.

Krumbein, W. C. \& Garrels, R. M. 1952: Origin \& Classification of Chemical Sediments in Terms of $\mathrm{pH}$ and Oxidation-Reduction Potentials. Jour. Geology 60, pp. 1-33.

Larsen, G., Liboriussen, J., Villumsen, A. 1972: Kvartærgeologiske undersøgelser på kortbladet Randers. Dansk Geol. Foren. Arsskr. 1971, pp. 27-40.

Marcussen, I. 1967: The freshwater molluscs in the Late-Glacial and Early PostGlacial deposits in the bog Barmosen, Southern Sjælland, Denmark. Meddr. Dansk Geol. Foren. 17, pp. 265-284.

MerTZ, E. L. 1924: Oversigt over De sen- og postglaciale Niveauforandringer i Danmark. Danmarks Geol. Unders. 2. række, 41.

Milthers, V. 1931: Israndens Tilbagerykning fra Østjylland til Sjælland-Fyn, belyst ved Ledeblokke. Nyere Iagttagelser - Djursiand. Meddr. Dansk Geol. Foren. 8, pp. $20-23$.

Mortimer, C. H. 1942: The Exchange of Dissolved Substances between Mud and Water in Lakes. Journal of Ecology, 30, pp. 147-201, and 29, pp. 280-329.

NAUMANN, E. 1917: Undersökninger öfver fytoplankton och under den pelagiske regionen försiggående gyttja- och dybildningar inom vissa syd- och mellansvenska urbergsvatten. K. Svenska Vetensk. - Akad. Handl. 56.

- 1919: Några synspunkter angående planktons ökologi. Med särskilt hensyn til fytoplankton. Svensk Bot. Tidsskr. 13.

Petersen, G. K. 1966: Redoxmeasurements. Radiometer.

voN Post, H. 1862: Studier öfver Nutidens Koprogena Jordbildningar, Gyttja, Dy, Torf och Mylla. K. Svenska Vetensk. - Akad. Handl. 4, pp. 1-59.

SteENSTRUP, J. 1842: Geognostisk-geologisk Undersøgelse af Skovmoserne Vidnesdam og Lillemose i det nordlige Sjælland. Vid. Sel, naturv. og mathem. Afh., IX Deel. København.

Sтокноцм, N. K. 1968: Senglaciale søaflejringer øst for Alborg ved Limfjordstunnelens Søndre Rampe. Meddr. Dansk Geol. Foren. 18, pp. 295-305.

Teichmüller, M. \& Teichmüller, R. 1967: Diagenesis of Coal. (Coalification). In: G. Larsen and G. V. Chilingar (Editors): Developments in Sedimentology 8, pp. 391-415.

ThIEDE, J. og Larsen, G. 1971: Radiographies of consolidated calcareous sediments from Denmark. Bull. Geol. Soc. Denmark, 20, pp. 307-328.

Thienemann, A. 1921: Seetypen. Die Naturwissenschaften. 18.

- 1925: Die Binnengewässer Mitteleuropas. Die Binnengewässer 1.

ThøGERSEN, F. 1942: Danmarks Moser. Beretning om Hedeselskabets systematiske Engog Moseundersøgelser.

Troels-Smith, J. 1951: Fossile Hængesække i Aamosen. Meddr. Dansk Geol. Foren. 12, pp. $177-178$.

- 1953: Ertebøllekultur - Bondekultur. Resultater af de sidste 10 aars Undersøgelser i Aamosen, Vestsjælland. Aarbøger for Nordisk Oldkyndighed og Historie, pp. 5-63.

- 1956: Vandstandssvingninger $\mathrm{i}$ indsøbassiner og havtransgressioner og regressioner. Meddr. Dansk Geol. Foren. 13, pp. 127-128.

Wesenberg-Lund, C. 1901: Studier over Søkalk, Bønnemalm og Søgytje i danske indsøer. Meddr. Dansk Geol. Foren. 2, nr. 7, pp. 1-180.

- 1917: Furesøstudier. K. Danske Vidensk. Selsk. Skr. 8. række, 3, pp. 1-208. 